\title{
Recent distribution and accumulation of organic carbon on the continental margin west off Spitsbergen
}

\author{
Daniel Winkelmann \\ Alfred Wegener Institute for Polar and Marine Research, Bremerhaven, Columbusstrasse, D-27568 Bremerhaven, \\ Germany
}

\author{
Jochen Knies \\ Geological Survey of Norway, N-7491 Trondheim, Norway (jochen.knies@ngu.no)
}

[1] The study compiles the controlling factors for organic matter sedimentation patterns from a suite of organogeochemical parameters in surface sediments off Spitsbergen and direct seabed observations using a Remotely Operated Vehicle (ROV). In addition we assess its storage rates as well as the potential of carbon sinks on the northwestern margin of the Barents Sea with short sediment cores from a selected fjord environment (Storfjord). While sedimentation in the fjords is mainly controlled by river/meltwater discharge and coastal erosion by sea ice/glaciers resulting in high supply of terrigenous organic matter, Atlantic water inflow, and thus enhanced marine organic matter supply, characterizes the environment on the outer shelf and slope. Local deviations from this pattern, particularly on the shelf, are due to erosion and out washing of fine-grained material by bottom currents. Spots dominated by marine productivity close to the island have been found at the outer Isfjord and west off Prins Karls Forland as well as off the Kongsfjord/Krossfjord area and probably reflect local upwelling of nutrient-rich Atlantic water-derived water masses. Accumulation rates of marine organic carbon as well as reconstructed primary productivities decreased since the middle of the last century. Negative correlation of the Isfjord temperature record with reconstructed productivities in the Storfjord could be explained by a reduced annual duration of the marginal ice zone in the area due to global warming. Extremely high accumulation rates of marine organic carbon between 5.4 and $17.2 \mathrm{~g} \mathrm{~m}^{-2} \mathrm{yr}^{-1}$ mark the Storfjord area, and probably high-latitude fjord environments in general, as a sink for carbon dioxide.

Components: 10,632 words, 9 figures, 3 tables.

Keywords: organic geochemistry; sediments; shelf; Spitsbergen.

Index Terms: 1051 Geochemistry: Sedimentary geochemistry.

Received 6 January 2005; Revised 12 May 2005; Accepted 8 August 2005; Published 20 September 2005.

Winkelmann, D., and J. Knies (2005), Recent distribution and accumulation of organic carbon on the continental margin west off Spitsbergen, Geochem. Geophys. Geosyst., 6, Q09012, doi:10.1029/2005GC000916.

\section{Introduction}

[2] Continental margins are known as high productive, and their storage of organic carbon play a major role in the global carbon cycle [e.g., Walsh, 1991; Wefer et al., 2003; Stein and Macdonald, 2003a, and contributions therein]. Despite their minor area, one fifth to one third of the global marine primary productivity $\left(8.3 \times 10^{9}{\left.\mathrm{t} \mathrm{OC} \mathrm{yr}^{-1}\right)}^{-1}\right.$
[Wollast, 1991, 2003] has been attributed to these locations. Hedges and Keil [1995] estimate that 45 percent of the preserved organic carbon is presently stored on the continental shelves (90 percent if deltas were included). However, apart from major carbon sinks, shelves are also considered to be sites of carbon recycling, i.e., organic carbon that escapes remineralization and is largely transported to deposition sites located on the continental slope 
[e.g., Walsh et al., 1981; Walsh, 1991; de Haas et al., 2002]. Regarding these conflicts, more information on organic sources, fluxes and storage rates along less explored margins is therefore necessary to constrain their impact on the size and residence of the organic carbon reservoir.

[3] Several recent studies have examined these issues in the Arctic Ocean and its marginal seas [e.g., Macdonald et al., 1998; Stein and Fahl, 2000; Stein et al., 2003; Stein and Macdonald, 2003a, and references therein]. These studies show that in contrast to the central Arctic Ocean with its continuous sea ice cover and low productivity, the marginal seas exhibit strong seasonal changes and higher surface water productivity [e.g., Stein and Macdonald, 2003a, and references therein]. For the Barents Sea, Slagstad and Wassmann [1997] modeled primary productivities between 40 and $100 \mathrm{gC}$ $\mathrm{m}^{-2} \mathrm{yr}^{-1}$, with the highest values confined to the marginal ice zone (MIZ). Enhanced stratification and availability of nutrients coupled with an increasing insolation during spring result in carbon pulses to the benthos [e.g., Owrid et al., 2000]. However, the export of phytoplankton biomass is largely controlled by micro- and mesozooplankton resulting in low sedimentation rates of living cells from the euphotic zone [Owrid et al., 2000], but explain the findings of high proportions of fecal pellets in sinking material [Andreassen et al., 1996].

[4] Unfortunately, the fate of particulate organic carbon deposited in marine sediments is less studied in the Barents Sea. Information on organic sources, diagenetic impregnation, and storage rates are very rare [e.g., Hulth et al., 1994; Stein et al., 1994; Glud et al., 1998]. In a recent compilation, Vetrov and Romankevich [2003] stated that most of the organic carbon deposited in the Barents Sea today is of marine origin and burial rates vary between 2.5 and $3.4 \times 10^{6} \mathrm{t} \mathrm{C}$ $\mathrm{yr}^{-1}$. However, this new compilation still lacks precision in terms of organic carbon sources, redistribution processes, and burial rates, particularly in the northern/northwestern part of the Barents Sea. First attempts to estimate the different proportions by using geochemical parameters yielded different results, which have been discussed controversially [Stein et al., 1994; Schubert and Calvert, 2001; Birgel and Stein, 2003]. Uncertainty about the origin of organic carbon and its storage rates in the northern Barents Sea yet remains. With the following study, we can close this gap of knowledge and provide new insights in the relationship between modern environmental processes, sediment accumulation, and storage rates of organic carbon in polar coastal environments.

[5] Here, we present new data illuminating the character and origin of organic carbon from the Spitsbergen continental margin as well as calculations of organic carbon storage rates in a highlatitude fjord environment. The purpose of this study is to examine (1) the characteristics of the sedimentary environment controlling the deposition of organic matter, (2) the sources of organic matter being deposited in fjords and seawards, (3) the role of high-latitude fjord environments as prominent storage site for terrestrial and marine organic matter, and (4) the characteristics of recent environmental parameters such as productivity, terrestrial input, ocean surface and bottom currents to establish a sound basis for paleoclimatic reconstructions.

\section{Environmental Setting}

[6] Spitsbergen, the main Island of the Svalbard Archipelago east of the Fram Strait forms the northwestern edge of the Barents Sea (Figure 1). Its geological spectrum provides an almost complete succession from Precambrian to Quaternary strata [Steel and Worsley, 1984; Dallmann, 1999]. Precambrian metamorphic crystalline rocks of the Heckla-Hoek group and sand-siltstones of Devonian ages predominate the northern and northwestern part. Nearly undisturbed strata of Mesozoic sedimentary rocks controls the central and southern parts of the island, while Tertiary organic-rich siliciclastic rocks with coal seams dominate the inner part of southern Spitsbergen [Michelsen and Khorasani, 1991]. The seafloor in the northwestern Barents Sea consists of Pleistocene moraines and of Holocene deposits including reworked morainic material [Dibner et al., 1970; Bjørlykke and Elverhøi, 1975]. Geophysical data indicate the presence of Mesozoic sediments immediately below the Pleistocene cover [Sundvor, 1974].

[7] Surface waters at the Spitsbergen continental margin are characterized by warmer Atlantic water $\left(\mathrm{T}>1{ }^{\circ} \mathrm{C} ; \mathrm{S} \sim 34.6\right)$ in the western and southern part and colder Arctic waters $\left(\mathrm{T}<0^{\circ} \mathrm{C}\right.$ and $\mathrm{S}<$ 34.4) with extensive sea ice cover in the eastern part separated by the polar front (Figure 1) [Loeng, 1991]. Ice melting during spring and summer creates a stratified and nutrient-rich euphotic zone, 


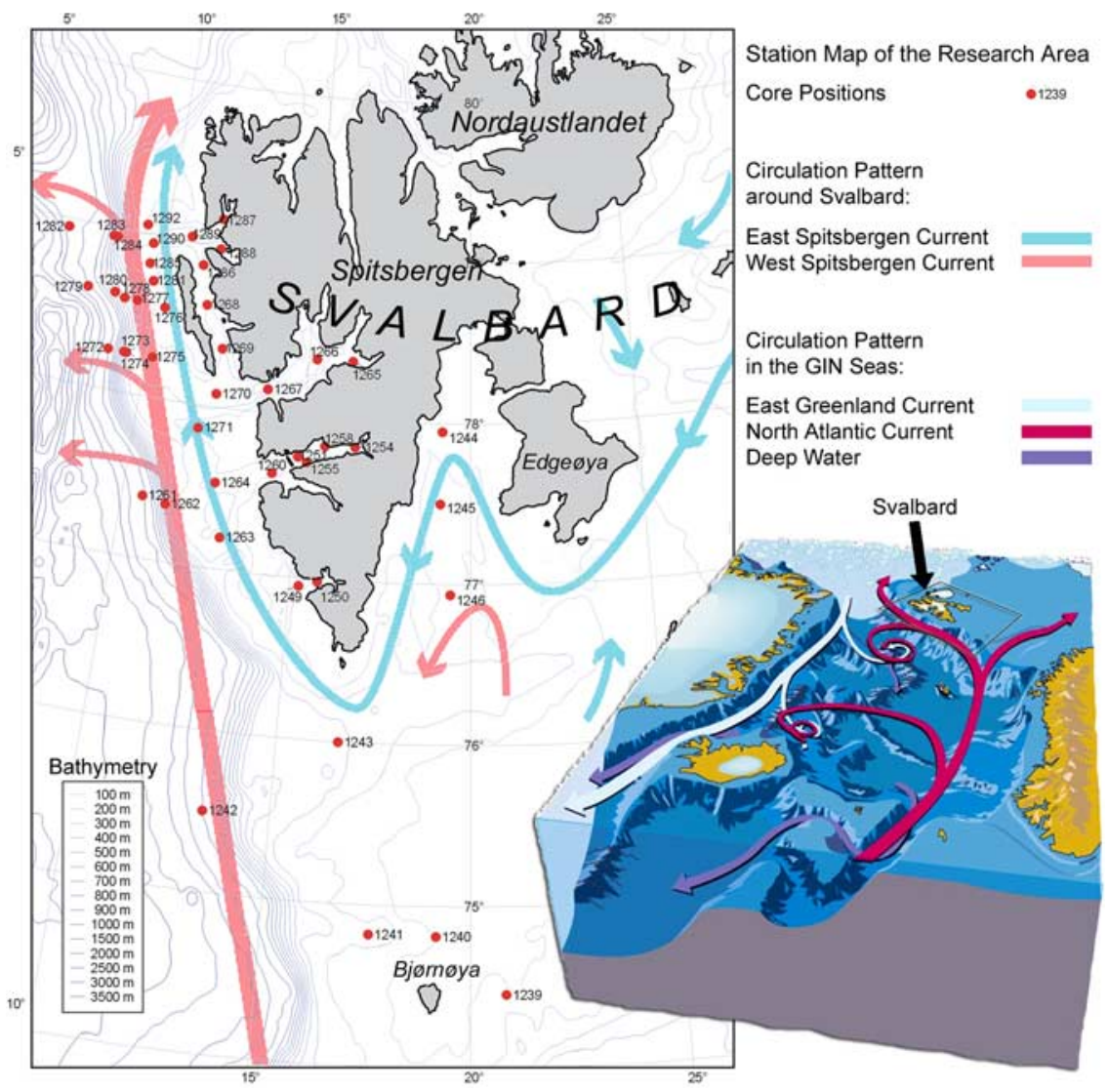

Figure 1. Research area, position of marine surface sediment samples, and surface circulation pattern; bathymetry from the IBCAO data set [Jakobsson et al., 2000]; box model with North Atlantic circulation pattern (source: Center for Environment and Resource Studies, University of Bergen).

which supports distinct plankton blooms along the marginal ice zone [e.g., Sakshaug and Slagstad, 1992; Owrid et al., 2000]. Ice coverage varies greatly from year to year probably reflecting the interannual dynamics of the Atlantic water inflow [Vinje, 2001]. These warm and nutrient-rich waters are capable of introducing extensive but variable amounts of zooplankton into the study area. Thus sea ice dynamics and related primary productivities affect carbon flux dynamics in the Barents Sea, and climate forcing is hence considered to play a significant role [Slagstad and Wassmann, 1997].

\section{Material and Methods}

[8] Forty-five short cores have been collected west off Svalbard and on the adjacent shelf to the south on a scientific cruise with $\mathrm{R} / \mathrm{V}$ Heincke in summer 2001. The short cores were either taken with a multicorer or with boxcoring equipment. Core description and first lithological descriptions were made directly after recovery.
Undisturbed surfaces of all short cores (first centimeter of core depth) and three cores from Storfjorden $(1244,1245,1246)$ were sampled and stored at $-20^{\circ} \mathrm{C}$ until analysis. Thereafter, all samples were freeze-dried and prior to grounding washed through $>1 \mathrm{~mm}$ mesh with deionized water excluding a substantial influence of possible ice rafted source rock/coal debris from the Barents Sea/Svalbard on the bulk geochemical and sedimentological signal [Bjorøy and Løberg, 1993] (see discussion below).

\subsection{Elemental Analysis}

[9] For the total organic carbon (TOC) analyses, aliquots $(\sim 200 \mathrm{mg})$ of the ground samples were treated with $10 \%$ (vol.) hydrochloric acid $(\mathrm{HCl})$ and heated to $60^{\circ} \mathrm{C}$ to remove carbonate, and then washed with purified water to remove all traces of $\mathrm{HCl}$. The possible loss of organic material by acid leaching is not taken into account. The samples were dried overnight $\left(50^{\circ} \mathrm{C}\right)$ and then analyzed. 
[10] Nitrogen analysis was performed on samples twice, on ground bulk sediment samples and after they had been treated with $\mathrm{KOBr}-\mathrm{KOH}$ solution to remove organic nitrogen from the sediment samples using the method of Silva and Bremner [1966]. Approximately $200 \mathrm{mg}$ of sediment was weighed into a beaker, covered with $10 \mathrm{ml}$ of freshly prepared $\mathrm{KOBr}-\mathrm{KOH}$ solution $(6 \mathrm{ml}$ bromine added at $0.5 \mathrm{ml} / \mathrm{min}$ to $200 \mathrm{ml}$ of $2 \mathrm{M} \mathrm{KOH}$ cooled with ice), and allowed to stand for 2 hours. $30 \mathrm{ml}$ of purified water was added to the beaker, which was then boiled vigorously for 5 minutes. Cooled overnight, the solution was decanted off and the slurry poured into a centrifuge tube the following day. The beaker was washed out with $0.5 \mathrm{~N} \mathrm{KCl}$ solution into the centrifuge tube, which was centrifuged for 10 minutes at $4000 \mathrm{rpm}$. Subsequently, the supernatant was decanted off before purified water was added to the tube. Shaken vigorously to disperse the sediments, the tube was centrifuged again for 10 minutes at $4000 \mathrm{rpm}$. After the supernatant was decanted off, the sediment pellet dried at $60^{\circ} \mathrm{C}$ in an oven overnight and was finally ground in-situ to a homogeneous powder before it was used for analysis.

[11] TOC was determined by means of a LECO CS 244 analyzer (Geological Survey of Norway). A Carlo Erba NC2500 analyzer (Iso-Analytical Ltd.) was used to measure the nitrogen contents of bulk $\left(\mathrm{N}_{\text {tot }}\right)$ and $\mathrm{KOBr}-\mathrm{KOH}$ treated sediments $\left(\mathrm{N}_{\text {inorg }}\right)$. The organic nitrogen $\left(\mathrm{N}_{\text {org }}\right)$ content has been determined by difference of $\mathrm{N}_{\text {tot }}$ and $\mathrm{N}_{\text {inorg }}$. Exchangeable nitrogen concentrations were not considered in this study. All bulk analyses are given in weight percentages (wt.\%). The reproducibility of TOC and $\mathrm{N}$ analyses is $\pm 15 \%$ and $\pm 10 \%$, respectively.

\subsection{Rock Eval Pyrolysis}

[12] For Rock Eval pyrolysis, aliquots of the crushed samples are weighed into crucibles $(\sim 100 \mathrm{mg})$ and analyzed in a Delsi Rock-Eval II instrument under the following conditions (cycle 1): $300^{\circ} \mathrm{C}$ isothermal for $3 \mathrm{~min}$., $25^{\circ} \mathrm{C} / \mathrm{min}$. temperature gradient, $390^{\circ} \mathrm{C} \mathrm{CO}_{2}$ trap shut off, $550^{\circ} \mathrm{C}$ isothermal for 1 min (cf. Espitalie et al. [1977] and Tissot and Welte [1984] for details). For the present study, the temperature at maximum pyrolytic hydrocarbon generation from kerogen (Tmax in ${ }^{\circ} \mathrm{C}$ ) was recorded to study the thermal maturity of the organic matter. Other results from the Rock Eval Pyrolysis will be published elsewhere. The IFP (Institut Français du Pétrole) Standard 55000 was used to check the precision of analysis $(10 \%$ duplicated) $\left( \pm 2^{\circ} \mathrm{C}\right.$ for Tmax $)$.

\subsection{Stable Isotope Analysis}

[13] Stable carbon isotope ratios of the organic fraction $\left(\delta^{13} \mathrm{C}_{\mathrm{TOC}}\right)$ were determined on decarbonated $(10 \% \mathrm{HCl})$ samples using a PDZ Europa elemental analyzer isotope ratio mass spectrometry (EA-IRMS, Iso-Analytical Ltd.). The $\delta^{13} \mathrm{C}_{\mathrm{TOC}}$ results are in per mil notation. $20 \%$ of the samples were analyzed in duplicate with an average standard deviation of $0.06 \%_{0}(n=18)$. The reference material was Iso-Analytical Ltd. working reference standard IA-Flour with a ${ }^{13} \mathrm{C}_{\mathrm{TOC}}$ value of $-26.43 \%$ versus Vienna-PDB. Along with IA-Flour, NBS-1577a (Bovine Liver, $\mathrm{d}^{13} \mathrm{C}_{\mathrm{TOC}}=-21.68 \%$ versus Vienna-PDB) was analyzed as quality control check samples during analysis of the sediments.

\subsection{Clay Minerals}

[14] For clay mineralogy, the $>63 \mu \mathrm{m}$ fraction was separated by wet sieving and the $<6 \mu \mathrm{m}$ fraction by Stoke's law settling method, respectively. The clay mineralogy measurements were carried out on a Philips X'pert MPD diffractometer with an automatic divergence slit, using $\mathrm{CuK} \alpha$ radiation $(40 \mathrm{kV}$, $50 \mathrm{~mA}$ ). Identification of clay minerals from XRD-pattern of ethylene glycol-treated samples was done at $10 \AA$ for illite, $17 \AA$ for smectite and $7 \AA$ for kaolinite and chlorite. To differentiate kaolinite and chlorite we used intensity ratios of the $3.58 \AA$-kaolinite peak and the $3.54 \AA$ chlorite peak. Relative clay-mineral contents were calculated by using empirical factors after Biscaye [1965] and normalized to 100\% (see Vogt et al. [2001] for more details). In this study, we solely present the relative illite contents in surface sediments. The remainder will be published elsewhere.

[15] The results of surface samples have been plotted with the Ocean Data View (ODV) software package [Schlitzer, 2002] using the Quick Gridding method to allow both interpolated special trend as well as spatial coverage information to be displayed.

\section{Chronology}

[16] The chronology of the three cores from the Storfjord is based on three $\mathrm{AMS}^{14} \mathrm{C}$ datings (Table 1) and the ${ }^{137} \mathrm{Cs}$ signal provided by the Gamma Dating Centre at Copenhagen, Denmark (Figure 2). $\mathrm{AMS}^{14} \mathrm{C}$ radiocarbon dating was performed on bivalve material from cores 1244 and 1245 at the Leibniz Laboratory for Dating and 
Table 1. Results of AMS ${ }^{14} \mathrm{C}$ Dating

\begin{tabular}{|c|c|c|c|c|c|}
\hline Core & Sample & $\begin{array}{c}\text { Depth } \\
\text { Interval, } \mathrm{cm}\end{array}$ & Species & $\begin{array}{l}\text { Conventional } \\
{ }^{14} \mathrm{C} \text { Age }\end{array}$ & $\begin{array}{c}\text { Reservoir } \\
\text { Corrected Age }\end{array}$ \\
\hline 1244 & KIA 17830 & $19-20$ & Astarte borealis, fragment & $455 \pm 25 \mathrm{BP}$ & $\begin{array}{l}\text { AD } 1900-1924 \\
1 \text { sigma cal AD } 1866-1950^{\mathrm{a}} \\
2 \text { sigma cal AD } 1822-1950^{\mathrm{a}}\end{array}$ \\
\hline 1245 & KIA 17829 & $7-8$ & Macoma calcarea, whole species & $<1954$ AD & no calibration \\
\hline 1245 & KIA 18578 & $20-21$ & benthic foraminifers & $440 \pm 20$ & no calibration \\
\hline
\end{tabular}

${ }^{\mathrm{a}}$ The corrected ages were calculated by using the CALIB 4.1 software package. A global reservoir correction of 402 years was applied.

Isotopic Research at the Christian-AlbrechtUniversity of Kiel and calendar ages were calibrated by the CALIB 4.1 software package with a correction for global marine reservoir effect of 402 years [Stuiver et al., 1998a, 1998b]. Thus radiocarbon ages below 450 years have not been calibrated. There are, however, regional values for reservoir correction different from the global average but while highly variable from site to site and not determined for the Storfjord area the established global value (402 years) has been applied.

[17] $\mathrm{AMS}^{14} \mathrm{C}$ ages are supported by the ${ }^{137} \mathrm{Cs}$ supply to the sediments, which show some similarities in all three cores (Figure 2). The marine environment in northern Europe reveals three major supply periods (events) during the last $\sim 100$ years: (1) the initial atmospheric nuclear bomb testing phase in the fifties to sixties, (2) the Sellafield outlets peaking in the mid-seventies, and (3) the Chernobyl reactor accident in 1986 [Kunzendorf and Larsen, 2002].
[18] Assuming an undisturbed recovery of all three cores in a low-energy, high-accumulation area of the Storfjord, we consider the core top to represent recent age (according to sampling year AD 2001). The first appearance of ${ }^{137} \mathrm{Cs}$ at $\sim 9.5 \mathrm{~cm}$ core depth in all cores has been used as the second time marker corresponding to the beginning of atmospheric nuclear testing in 1952 AD (H. Kunzendorf, personal communication, 2002) (Figure 2). A third time indicator arises from the $\mathrm{AMS}^{14} \mathrm{C}$ results for cores 1244 and 1245 which gave about the same uncorrected age (within the error ranges) corresponding to a time interval between 1900 and 1924 at about 20 centimeter core depth (Figure 2). Given these three time markers and by assuming a constant sedimentation rate for the cores a linear age model can be established for all three cores (Figure 2). On the basis of the age model, bulk mass accumulation rates $\left(\mathrm{MAR}_{\text {bulk }}\right)$ can be calculated as $\mathrm{MAR}_{\text {bulk }}=\mathrm{LSR} \times \mathrm{DBD}$, where LSR $=$ linear sedimentation rate and $\mathrm{DBD}=$ dry bulk density (data taken from Winkelmann

\section{Final Age Model for all three cores}

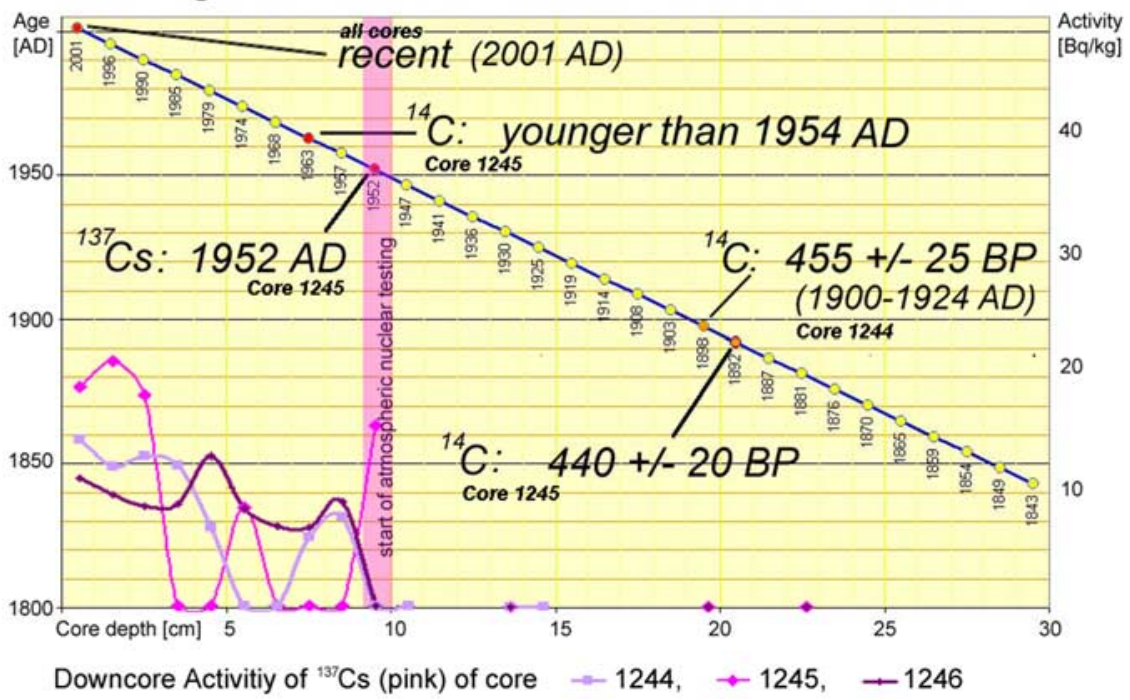

Figure 2. Linear age model for the cores based on first appearance of ${ }^{137} \mathrm{Cs}$ at $9.5 \mathrm{~cm}$ core depth and supported by AMS radiocarbon dating of Cores 1244 and 1245. 
Table 2. Selected Mass Accumulation Rates for the Three Cores of Storfjorden ${ }^{\text {a }}$

\begin{tabular}{lllr}
\hline \multicolumn{1}{c}{ MAR } & \multicolumn{1}{c}{1244} & \multicolumn{1}{c}{1245} & 1246 \\
\hline MAR $_{\text {bulk }}$ & $890-1750(2240)$ & $570-1470$ & $600-1620$ \\
MAR $_{\text {TOC }}$ & $21-40(50)$ & $14.6-36.3$ & $11.7-35.2$ \\
MAR $_{\text {M-OC }}$ & $5.8-11.7(13.8)$ & $6.9-16.3$ & $5.4-17.2$ \\
MAR $_{\text {T-OC }}$ & $15.1-29(37.2)$ & $7.7-20.8$ & $6.3-18.7$ \\
\hline
\end{tabular}

\footnotetext{
${ }^{\mathrm{a}}$ Mass accumulation rates are in $\mathrm{g} \mathrm{m}^{-2} \mathrm{yr}^{-1}$.
}

[2003]). The corresponding LSR is $183.7 \mathrm{~cm}$ $\mathrm{kyr}^{-1}$. The MAR bulk varies between 89 and 224 (core 1244), 57 and 147 (core 1245) and between 60 and 162 (core 1246) $\mathrm{g} \mathrm{cm}^{-2} \mathrm{kyr}^{-1}$ (Table 2).

\section{Results and Discussion}

\subsection{Sedimentary Environment}

[19] The sedimentary environments have been characterized with the aid of pictures of a Remotely Operated Vehicle (ROV “sprint 103") (Figure 3) equipped with a video and still camera, a compass and two parallel orientated laser beams (distance $32 \mathrm{~cm}$ ) which act as a scale in the images (Julian Gutt, Alfred Wegener Institute for Polar and Marine Research, personal communication, 2002). Accordingly, we simply divide the sedimentary environment in the study area between (1) a high-energy, no accumulation environment on the outer shelf/shelf break and bathymetric highs, (2) a low-energy, high-accumulation environment in the inner fjords, and (3) a mixed type of moderate or variable energy, low-accumulation environment of the transitional sites and the Barents Sea. Especially the winnowed lag deposits on the outer shelf (e.g., stations $1250,1262,1273,1274$ ) are considered to represent erosional surfaces probably induced by contour or bottom currents [Andruleit et al., 1996]. The "ice-rafted debris (IRD) signal" of these hard ground surfaces may not reflect recent ice rafting but out washing of finer sediments. The onset of increased along-shelf bottom currents was dated to approximately $2.6 \mathrm{kyr}$ BP [Andruleit et al., 1996]. Possible reasons could be a postglacial reorganization of the oceanographic conditions [Svendsen and Mangerud, 1997] or a lowering of the sea level $(\sim 50 \mathrm{~m})$ during the postglacial isostatic rebound [Landvik et al., 1992] resulting in a higher energetic regime at the seafloor [Boulton, 1990]. The winnowing facies is observed on the shelf to water depth $>130$ mbsf west off Prins Karls Forland. Toward the incisions of the fjord systems, areas are

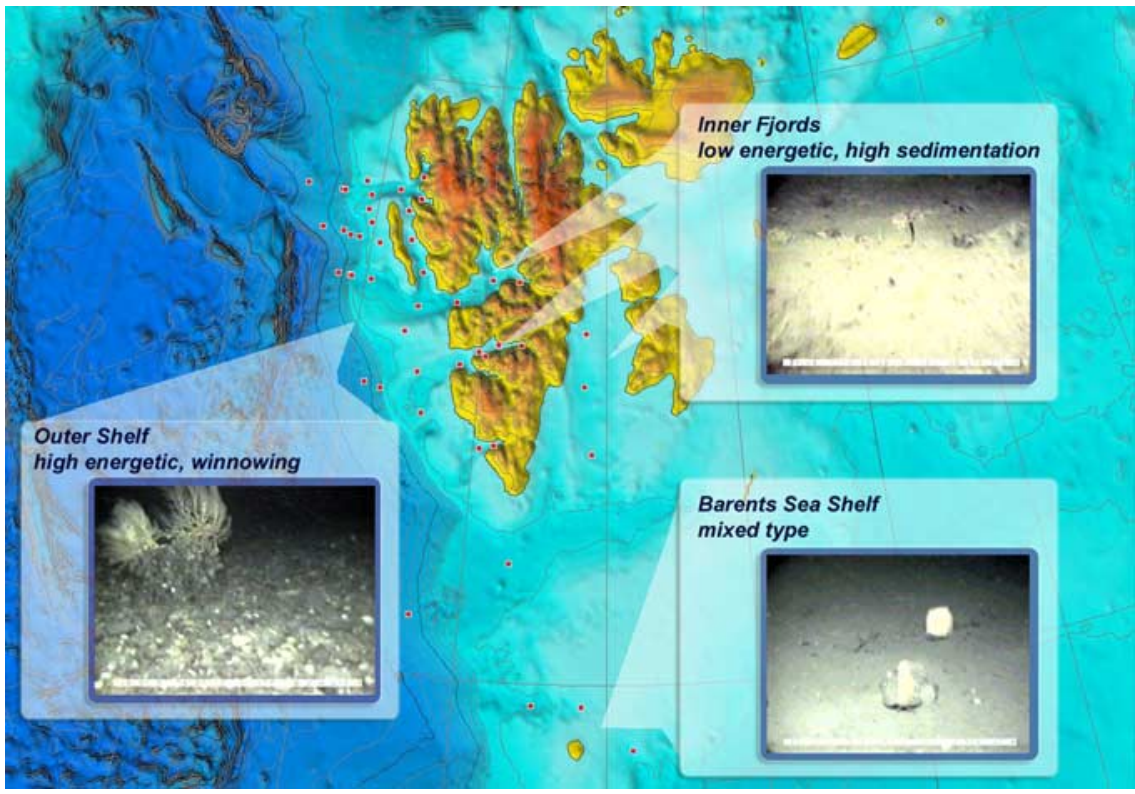

Figure 3. Three types of sedimentary environment: outer shelf, high energetic (no sedimentation); inner fjords, low energetic (high sedimentation); Barents Sea shelf, mixed type of medium energetic (low sedimentation) (based on interpretation of ROV pictures). 
sheltered from the bottom currents and therefore sites favoring deposition. In fact, high terrigenous input due to glacial erosion and glacio-fluvial processes as well as extreme particle flux may have caused thick sedimentary sequences in the inner fjords [e.g., Elverhøi et al., 1995; Hop et al., 2002; Plassen et al., 2004]. In contrast, the sediments from the Barents Sea shelf exhibit partly features of the higher energetic shelf environments west off Spitsbergen. Within the Atlantic water domain, strong bottom currents $(\sim 0.5 \mathrm{~m} / \mathrm{sec}$, based on ROV observation) leave single ice rafted boulder outstanding. Although not analyzed for grain sizes, sediments from these sites were found sandier during sampling preparation. Autumn and winter storms may also contribute to this sedimentological picture of a higher energetic environment [Rumohr et al., 2001; Sarnthein et al., 2003], but, in general, resuspension, entrainment and lateral displacement of fine grained sediments seem to be not as dominant as on the shelf west off Spitsbergen.

\subsection{Sources and Pathways of Organic Carbon at the Spitsbergen Continental Margin}

\subsubsection{Carbon and Nitrogen Contents}

[20] Total organic carbon (TOC) measurements show relatively high values varying between 0.5 and $2.7 \mathrm{wt} . \%$. Highest values are found in samples from the Storfjord and the Isfjord but some samples from off the Kongsfjord/Krossfjord area exhibit similarly elevated values (Figure 4, Table 3). Pronounced low values characterize the continental shelf and slope but are low as well in the Krossfjord and north of Bear Island. Distribution of $\mathrm{N}_{\text {tot }}$ shows no distinct pattern, but a rather complex picture, as relatively high and low values are present in fjords and on the shelf (Figure 4, Table 3). However, lower values characterize fjord heads of the Isfjord and the Van Mijenfjord whereas lowest values are found on the shelf slope west off Spitsbergen. The distribution of the inorganic nitrogen $\left(\mathrm{N}_{\text {inorg }}\right.$ ) contents clearly shows highest values in the fjords with strong gradients to open marine or shelf environments (Figure 4, Table 3). The distribution of the organic nitrogen $\left(\mathrm{N}_{\text {org }}\right)$ shows relatively low values at fjord heads as well as on the shelf slope (Figure 4, Table 3). Relatively higher values are present off Prins Karls Forland and off the Kongsfjord/Krossfjord area. The short cores, here exemplified on 1245, reveal no significant temporal deviation from the surface samples for all proxies (Figure 4). One exception is the sudden decrease in organic nitrogen at the sediment surface that is probably the result of a preferential diagenetic remineralization and uptake of nitrogen by benthic organisms.

\subsection{2. $\mathrm{C} / \mathrm{N}$ Ratios and Clay Minerals}

[21] $\mathrm{TOC} / \mathrm{N}_{\text {tot }}$ ratios, commonly quoted as $\mathrm{C} / \mathrm{N}$ values are widely used as a tool for discriminating marine from terrestrial organic matter in sediments [Müller et al., 1983; Stein, 1991; Hebbeln and Berner, 1993; Wagner and Dupont, 1999]. However, in clay-rich sediments with high proportions of illite (the clay mineral mainly responsible for ammonium binding) it is important to distinct between organic and bound inorganic nitrogen [e.g., Müller, 1977; Schubert and Calvert, 2001]. For instance, Schubert and Calvert [2001] found that nearly $50 \%$ of the total nitrogen content in central Arctic Ocean surface sediments is composed of the inorganic fraction. They suggested TOC/ $\mathrm{N}_{\text {org }}$ ratios for interpreting organic matter sources in the Arctic Ocean.

[22] In fact, TOC/ $\mathrm{N}_{\text {tot }}$ ratios in surface samples off Spitsbergen are apparently affected by inorganic nitrogen too, which results in generally lower TOC $/ \mathrm{N}_{\text {tot }}$ (roughly between 5 and 15) compared to $\mathrm{TOC} / \mathrm{N}_{\text {org }}$ ratios (between 8 and 49) (Figure 5, Table 3). A similar offset is also observed in sediment records from the Storfjord (Figure 5). The dominance of illite in the clay fraction in all samples (Figure 4) may support that the $\mathrm{TOC} / \mathrm{N}_{\text {tot }}$ ratios are altered by inorganic nitrogen bound as ammonium into the lattice structure of the clay mineral. However, illite contents in fine fraction do not correlate with absolute values of inorganic nitrogen. Instead, highest inorganic nitrogen contents, and thus strongest deviations between $\mathrm{TOC} /$ $\mathrm{N}_{\text {tot }}$ and TOC/ $\mathrm{N}_{\text {org }}$ ratios are closely related to the high amounts of fine-grained material deposited in the inner fjords. This indicates that the depositional environment is more relevant for the disturbance of $\mathrm{C} / \mathrm{N}$ ratios through inorganic nitrogen than the dominance of single clay minerals. Considering the common use of $\mathrm{C} / \mathrm{N}$ ratios to illuminate controlling processes for organic matter sedimentation in other high-latitude depositional settings [Stein and Macdonald, 2003a, and references therein], and comparing this with the fact that inorganic nitrogen can account for up to $70 \%$ of the total nitrogen content (this study), it is highly recommended to calculate the fraction of inorganic nitrogen before assessing sources of organic matter and potential storage rates [e.g., Muzuka and HillaireMarcel, 1999; Schubert and Calvert, 2001]. 
TOC $(w t \%)$ in surface sediments

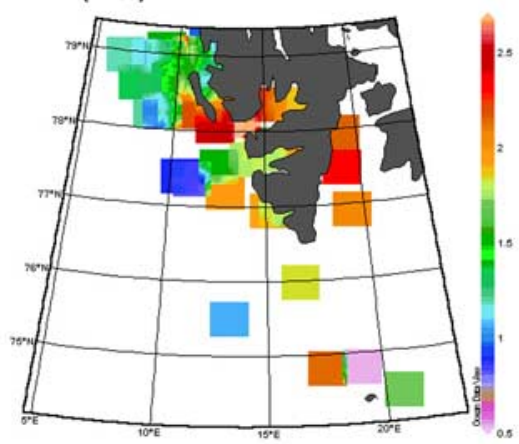

$N_{\text {tot }}(w t \%)$ in surface sediments

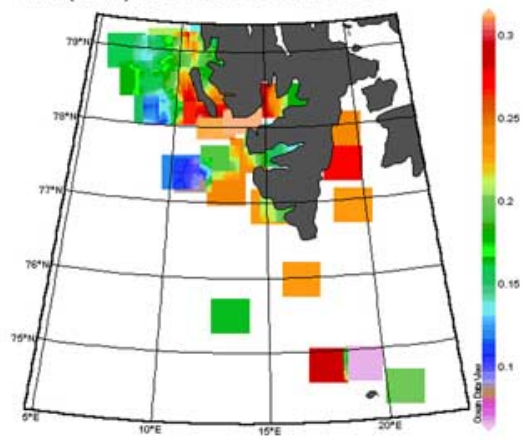

Illite $(\%)$ in surface sediments

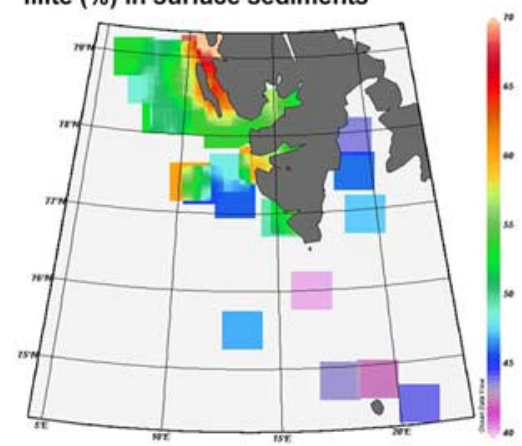

Norg $(w t \%)$ in surface sediments

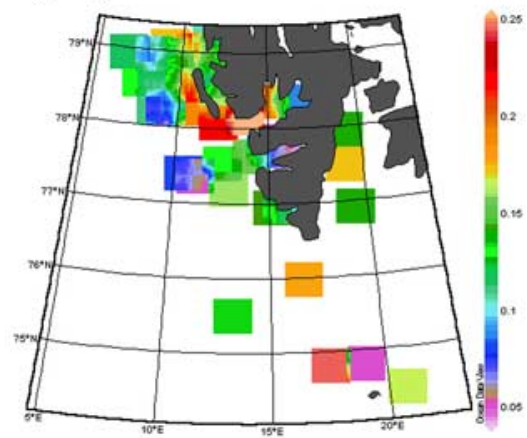

$\mathrm{N}_{\text {bnd }}(w t \%)$ in surface sediments

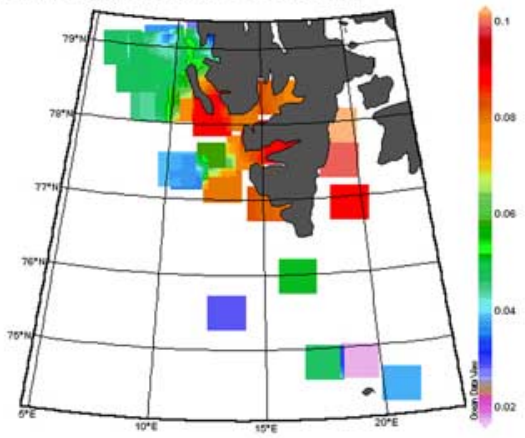

Downcore trends in Storfjorden (core 1245)

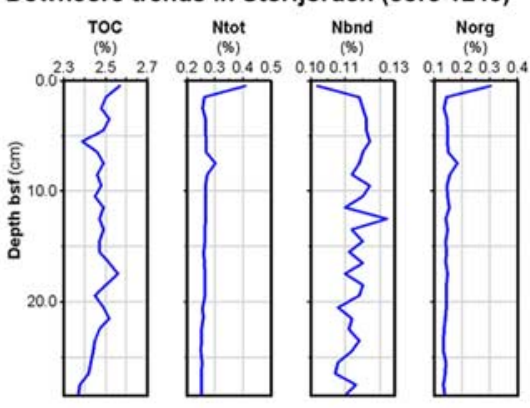

$\max : 28.5 \mathrm{~cm}$

Figure 4. Distribution of total organic carbon (TOC), nitrogen $\left(\mathrm{N}_{\text {tot }}=\right.$ total nitrogen, $\mathrm{N}_{\text {org }}=$ organic nitrogen, $\mathrm{N}_{\mathrm{bnd}}=$ inorganic nitrogen) and illite (relative percentage of clay mineral assemblage) in surface sediments off Spitsbergen, as well as downcore trends of TOC, $\mathrm{N}_{\text {tot }}, \mathrm{N}_{\text {org }}$, and $\mathrm{N}_{\text {bnd }}$ in selected core 1245 from the Storfjord.

[23] TOC/ $\mathrm{N}_{\text {org }}$ ratios from the outer shelf areas vary between 8 and 21, with a mean value of $\sim 11.4$ indicative for enhanced input of marine organic matter [Stein, 1991; Tyson, 1995; Wagner and Dupont, 1999]. The highest values $(>16)$ in three sites $(1262,1273,1274)$ likely represent non-recent values and may reflect their erosional sedimentary environments, i.e., winnowed lag deposits caused by contour currents (Figure 3). $\mathrm{TOC} / \mathrm{N}_{\text {org }}$ ratios from inner fjord environments are significantly higher than those from shelf areas (Figure 5). With ratios ranging between 11 (1266, Isfjord) and 49 (1254, Van Mijenfjord) (mean $\sim 16.5$ ) (Figure 5) these sites are characterized by terrigenous dominated organic material [Scheffer and Schachtschnabel, 1984] most likely introduced by river discharge, coastal erosion and IRD from nearby glaciers. The extraordinary high TOC/Norg ratios (49) accompanied with light $\delta^{13} \mathrm{C}_{\mathrm{TOC}}$ values $(\sim-25 \%)$ in Van Mijenfjorden samples may be explained by nearby mining activities of highvolatile bituminous inertinite-rich coals in the Norwegian community of Braganza Bay (Svea mine) [Khorasani and Michelsen, 1991; Michelsen and Khorasani, 1991] or input of Mesozoic organic-rich shales and siltstones [Mørk and Bjorøy, 1984], which would accordingly be responsible for an enhanced input of fossil organic material. However, Rock Eval Tmax values of generally $<430^{\circ} \mathrm{C}$ in all surface sediments of the van 


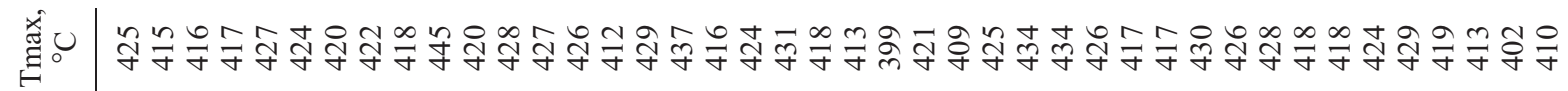

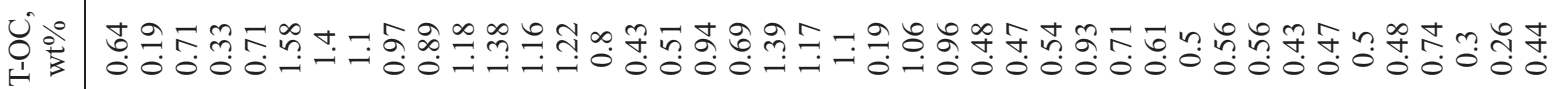

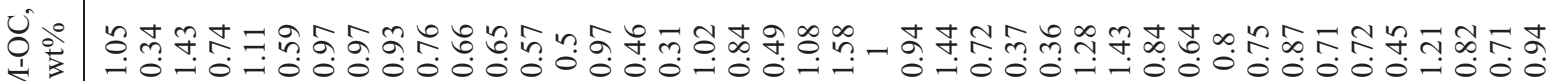
$\Sigma$

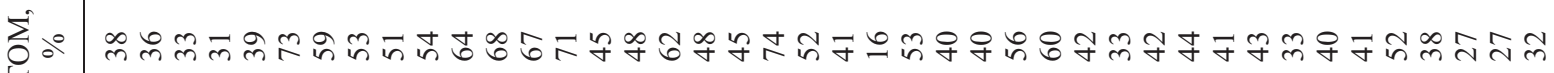

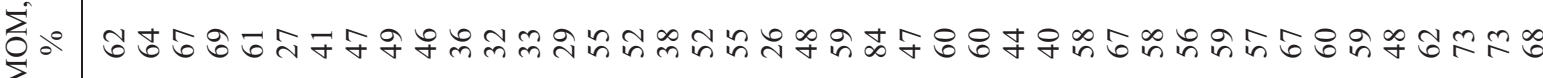

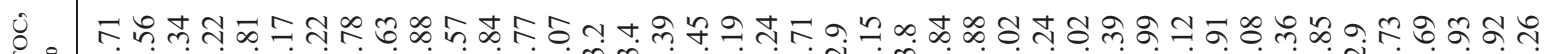

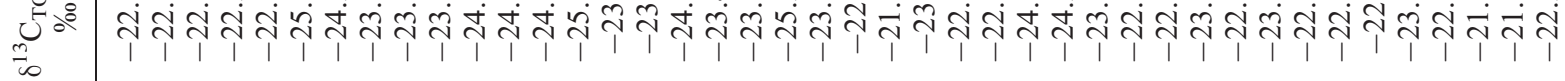

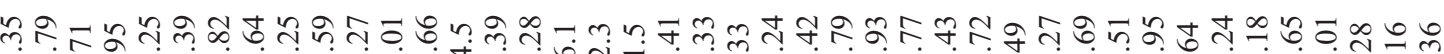

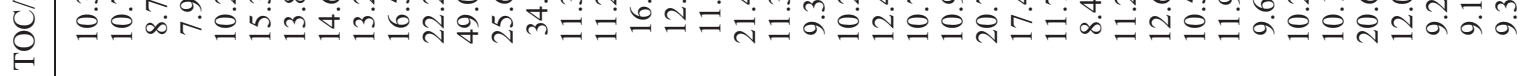

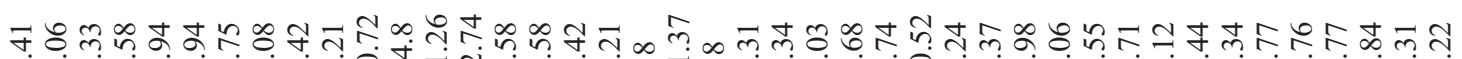

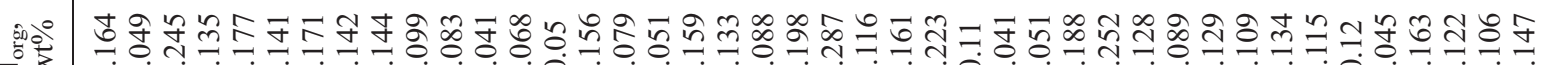

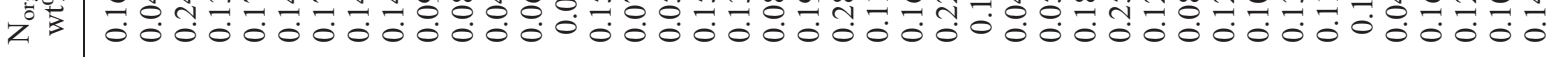

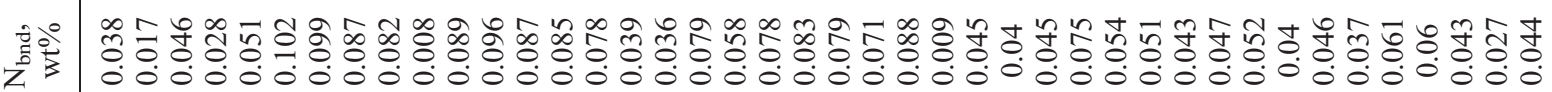

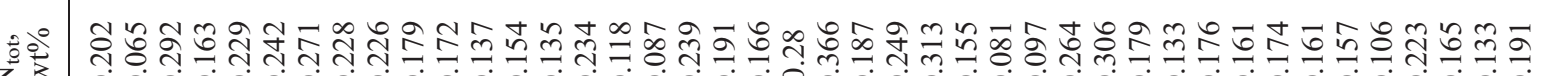
Z 300000000000000000000000000000000000000000

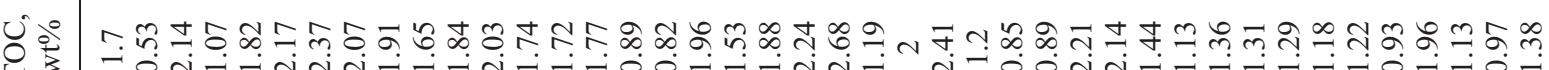

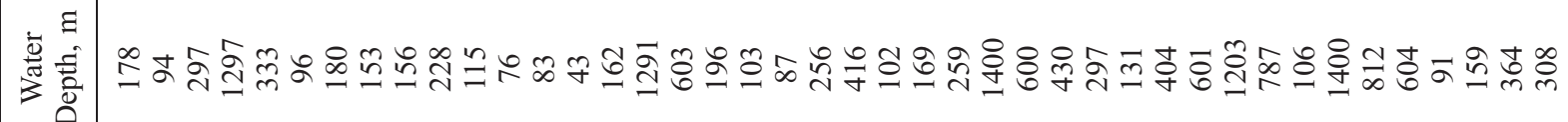

造 实

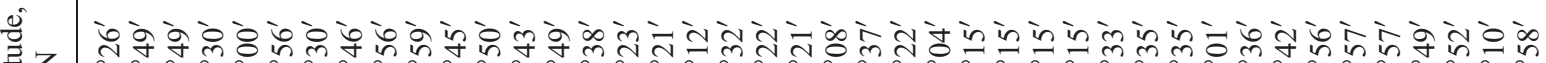

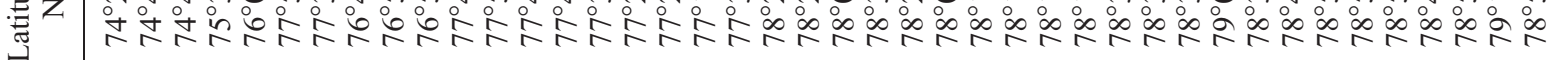




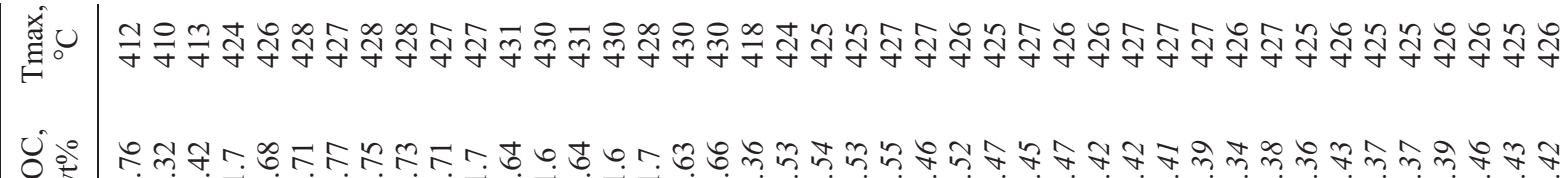

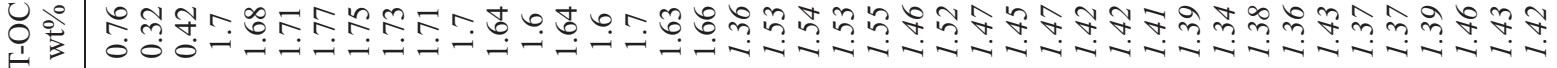

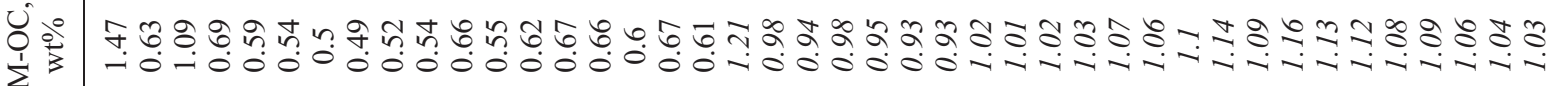

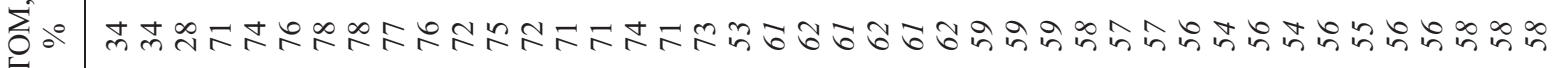

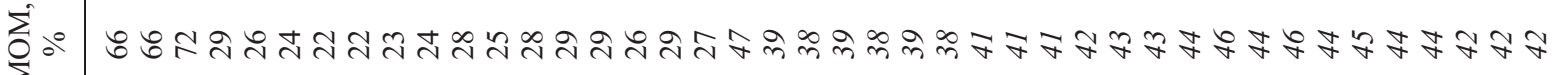

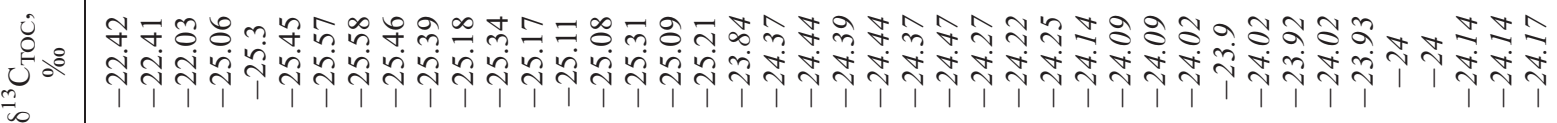

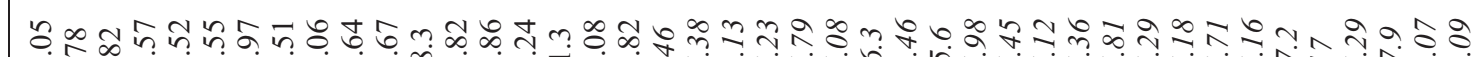

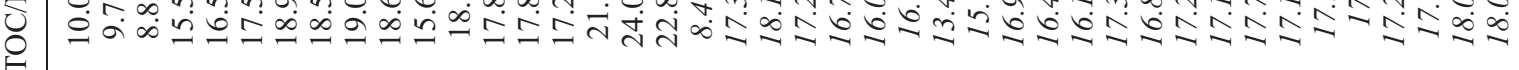

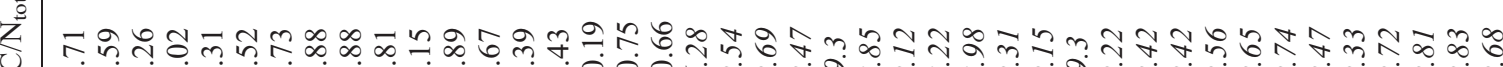

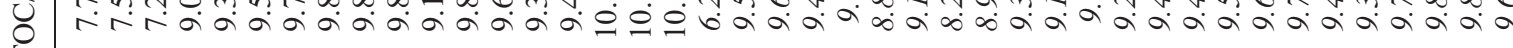

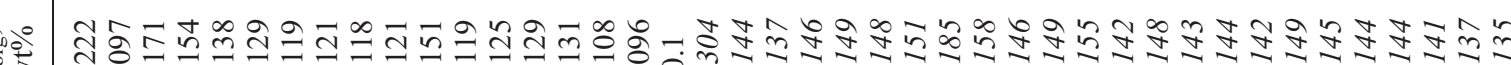

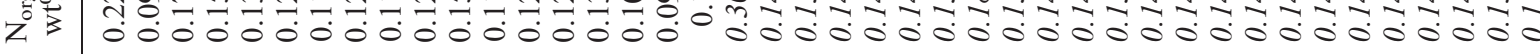

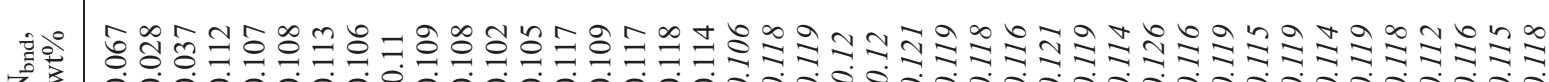

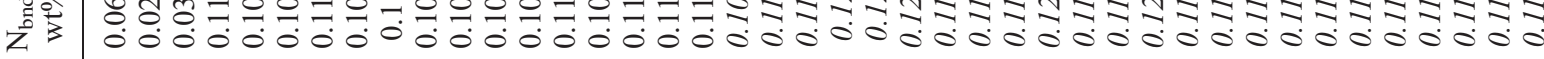

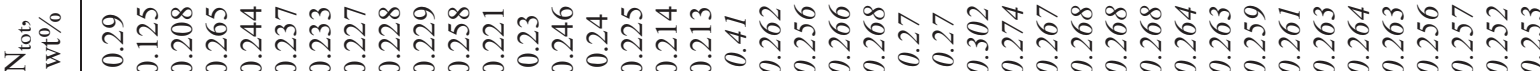

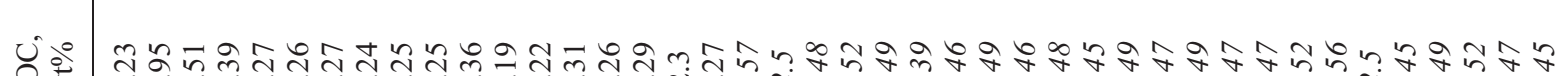
००

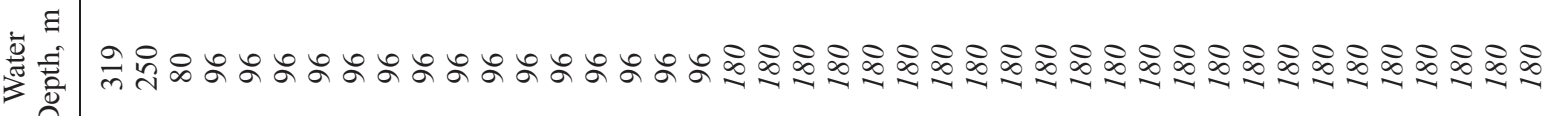

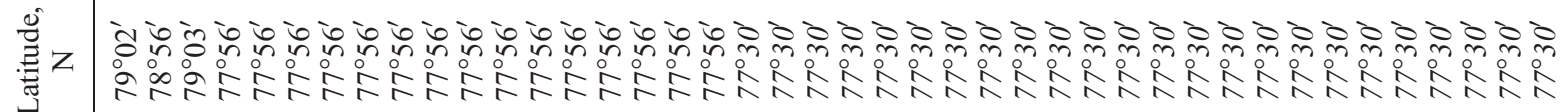

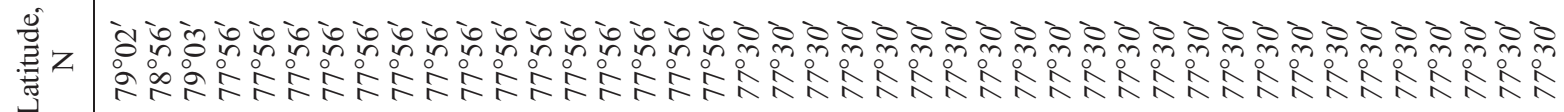

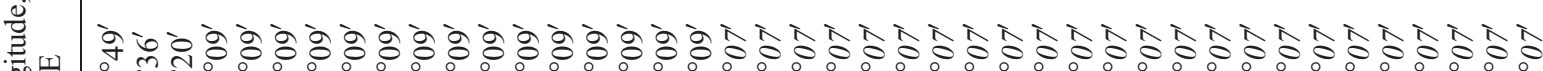
○ัง ฮั

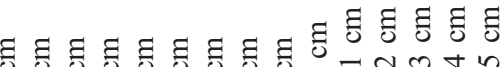

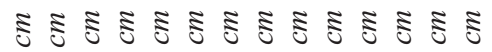

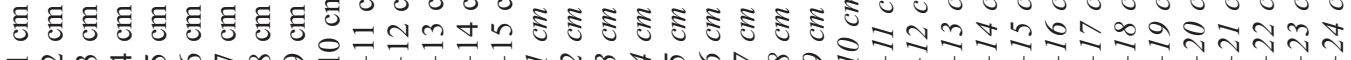

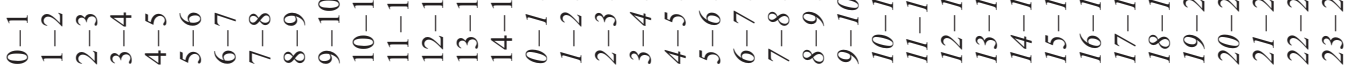

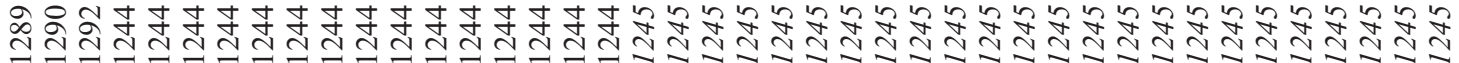




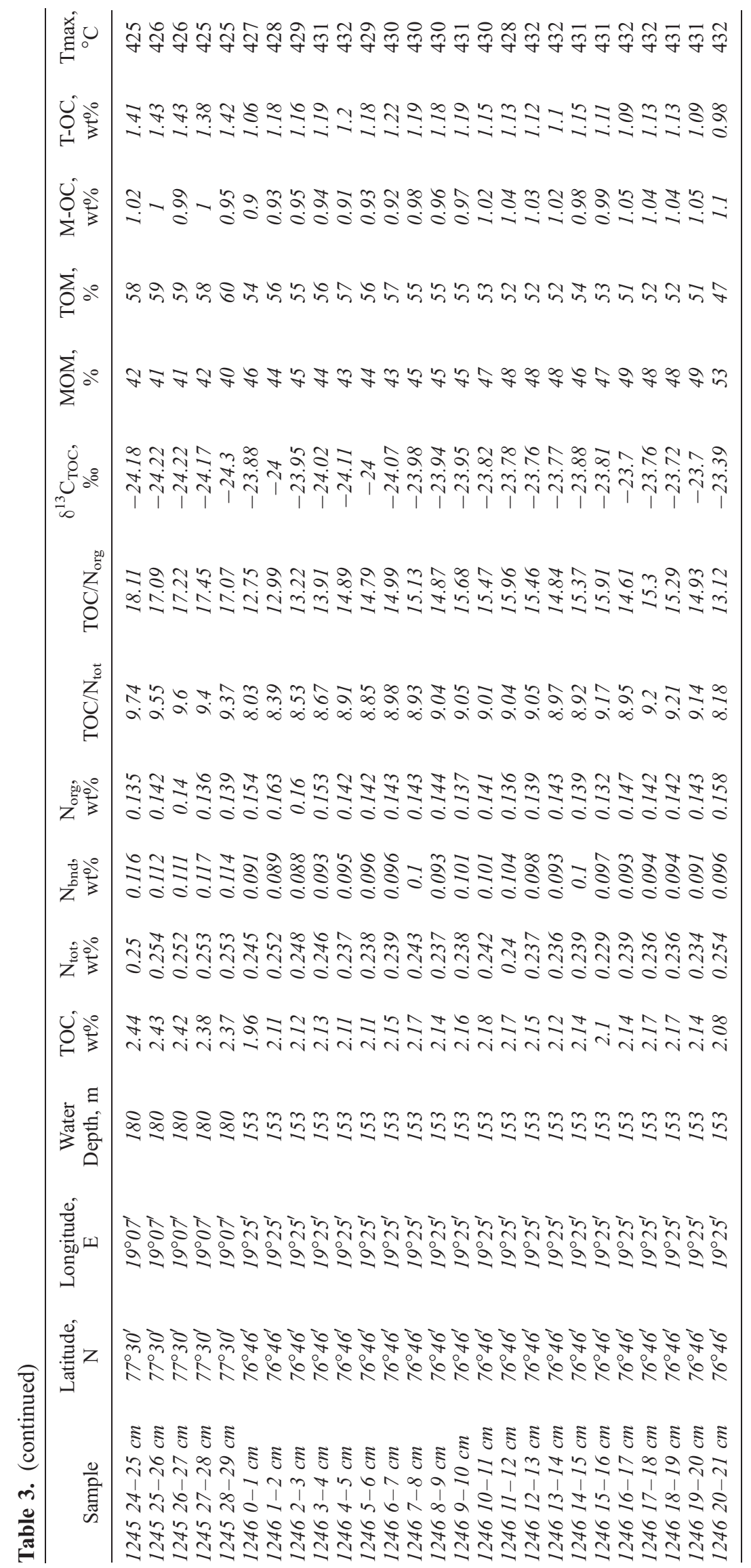




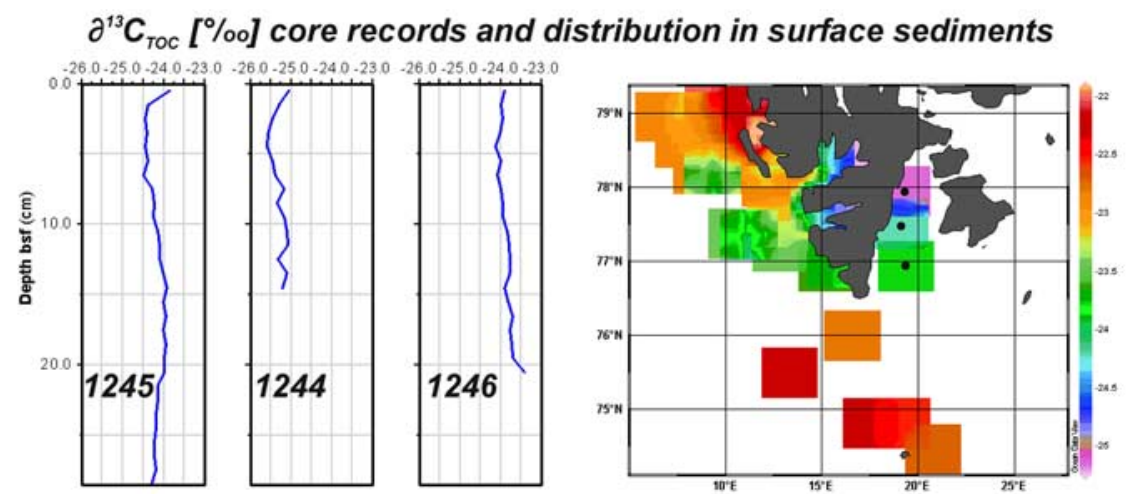

$T O C / N_{\text {tot }}$ core records and distribution in surface sediments
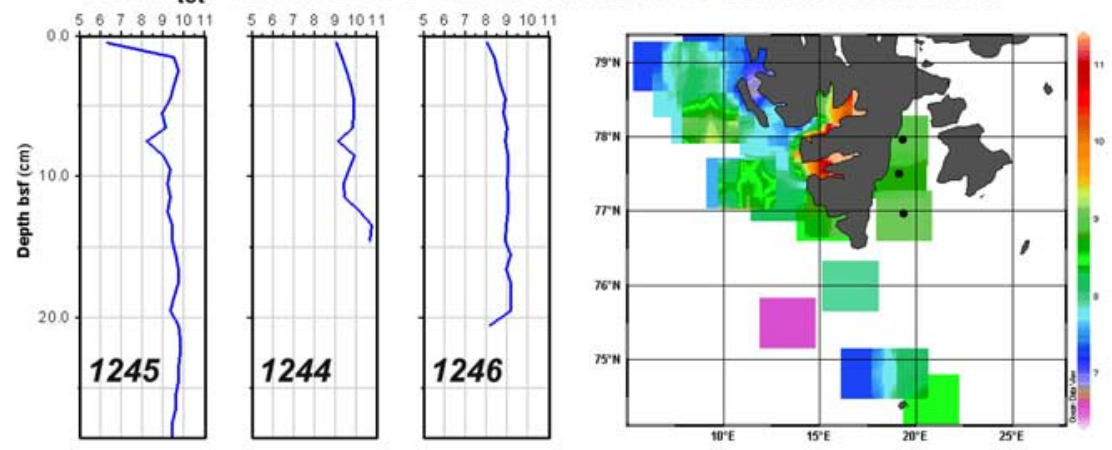

$T O C / N_{\text {org }}$ core records and distribution in surface sediments
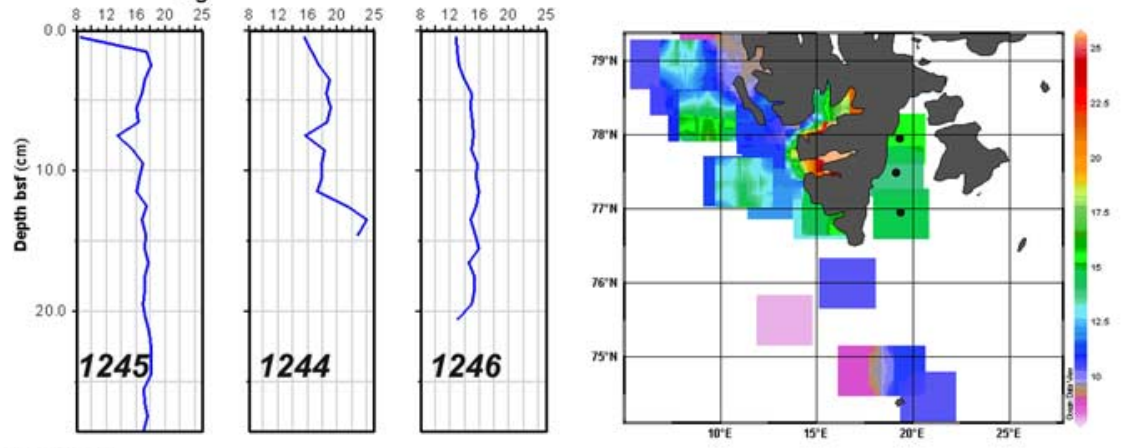

Figure 5. The $\delta^{13} \mathrm{C}_{\mathrm{TOC}}$, TOC/ $\mathrm{N}_{\text {tot }}$, and $\mathrm{TOC} / \mathrm{N}_{\text {org }}$ ratios in surface sediments off Spitsbergen (right) and three records (cores 1245, 1244, 1246) from the Storfjord.

Mijenfjorden and Isfjorden (Table 3) indicate a rather immature character of the bulk organic matter and may reflect a subordinate importance of this fossil organic carbon input for the recent sedimentary environment.

\subsubsection{Stable Carbon Isotopes}

[24] Stable isotopic composition of organic matter $\left(\delta^{13} \mathrm{C}_{\mathrm{TOC}}\right)$ has been used to determine quantitative proportions of terrestrial derived organic carbon in recent environments in the Arctic realm [e.g., Müller-Lupp et al., 2000; Schubert and Calvert, 2001; Fahl et al., 2003]. C3 plant derived terrestrial organic carbon reveals depleted $\delta^{13} \mathrm{C}_{\mathrm{TOC}}$ values between -25.5 and $-29.3 \%$, with an average end-member signature of -27\%o [e.g., Ruttenberg and Goñi, 1997; Rachold and Hubberten, 1999; Naidu et al., 2000]. The admixture of $\mathrm{C} 4$ plant debris in these higher latitudes is of less importance [Teeri and Stowe, 1976]. However, to quantify marine organic carbon proportions, the use of paired analyses of specific organic biomarker (n-alkanes) or bulks (C/N ratios) and the $\delta^{13} \mathrm{C}_{\mathrm{TOC}}$ signatures of contemporaneous sedimentary organic matter is recommended [Jasper and Gagosian, 1989, 1990]. 
[25] The $\delta^{13} \mathrm{C}_{\text {TOC }}$ values in surface sediment samples off Spitsbergen vary between $-21.1 \%$ and $-25.2 \%$ (ø $-23.2 \%, \mathrm{n}=45$ ) (Table 3). Distribution patterns of $\delta^{13} \mathrm{C}_{\mathrm{TOC}}$ show well-developed gradients from locations of the inner fjords toward more distal or marine sites on the shelf (Figure 5). An exception from that picture constitutes surface sediments from the Kongsfjord/Krossfjord area where $\delta^{13} \mathrm{C}_{\mathrm{TOC}}$ values are generally $>-22.5 \%$. In addition, relative light values $(\leq-24.0 \%)$ together with increased $\mathrm{TOC} / \mathrm{N}_{\text {org }}$ ratios $(>16)$ on highs of the outer shelf and shelf break west off Spitsbergen (stations 1262, 1273, 1274) as well as the outer Hornsund in the south of Spitsbergen (station 1250) could reflect the local sedimentation pattern characterized by winnowing and erosion as documented by ROV observations in Figures 3 and 5 [cf. Andruleit et al., 1996]. Here, impregnation of surface sediments by exposed Mesozoic rocks underlying the Pleistocene cover in the northwestern Barents Sea may be possible (Figure 3). If admixed in minor proportions as erosional debris to the marine sediment flux, the geochemical and isotopic signatures of modern sediments may be changed. Indeed, Rock Eval Tmax values in these selected samples are generally higher $\left(>435^{\circ} \mathrm{C}\right)$ than in all other samples (Table 3 ) pointing to an admixture of fossil organic carbon as frequently observed in glacial and deglacial sediments from the eastern Norwegian-Greenland Sea [Wagner and Henrich, 1994; Henrich et al., 1995; Wagner and Hölemann, 1995]. This is consistent with the geochemical characterization of these Mesozoic, TOC-rich shales and siltstones exemplary collected in Pleistocene morainic material from the northwestern Barents Sea where Rock Eval Tmax and vitrinite reflection (Ro) values vary between $\sim 450-485^{\circ} \mathrm{C}$ and $0.5-1.0 \%$, respectively [Bjorøy and Vigran, 1980]. However, for the other samples admixture is probably of minor importance as the Rock Eval Tmax average value for these samples is significantly lower $\left(419 \pm 7^{\circ} \mathrm{C}\right)$ (Table 3$)$ suggesting a dominance of immature material in the bulk organic signal.

[26] Minimum changes in $\delta^{13} \mathrm{C}_{\mathrm{TOC}}$ are observed downcore at all sites in the Storfjord (Figure 5). Together with rather uniform organic and nitrogen contents, this points toward minimum diagenetic alteration [e.g., Freudenthal et al., 2001] and therefore to a fair preservation of organic matter in the Storfjord possibly induced by very high sedimentation rates ( $2 \mathrm{~mm} /$ year). More obvious is the spatial gradient from the inner $(\varnothing-25.3 \%)$, to the middle $(\varnothing-24.2 \%)$, and outer station (ø
$-23.8 \%$ ). This variability is characterized by systematic trends and thus considered to reflect changes in sedimentary environment rather than early diagenetic effects. The ranges of the individual records are consistent with gradients seen in $\delta^{13} \mathrm{C}_{\mathrm{TOC}}$ of surface sediments. This suggests organic matter source dependant variability from the inner fjords (more terrigenous) to the shelf (more marine) similar to the findings from the Laptev, Kara, and Beaufort seas [Stein and Macdonald, 2003a, and references therein]. Admixture of TOCrich siltstones/shales and coals abundant in the Mesozoic of southeastern Spitsbergen [Mørk and Bjorøy, 1984; Michelsen and Khorasani, 1991] is probably of minor importance as the Rock Eval Tmax values in the investigated sediment cores are more or less constant (Table 3) with an average value of $427 \pm 2.7^{\circ} \mathrm{C}$ which is significantly lower than known regional variations in Rock Eval Tmax from bedrock samples $\left(445-470^{\circ} \mathrm{C}\right)$ and not coherent with high-volatile bituminous $(\mathrm{Ro}=\sim 0.6 \%)$ or coked coals nearby in the catchment area [Mørk and Bjorøy, 1984; Michelsen and Khorasani, 1991].

\subsubsection{Two-End-Member Mixing Model}

[27] The $\delta^{13} \mathrm{C}_{\text {TOC }}$ variability in sediment surfaces and records is widely used to determine relative proportions of terrestrial and marine derived organic matter by application of a two-end-member mixing model [e.g., Jasper and Gagosian, 1989; Westerhausen et al., 1993; Wagner and Dupont, 1999; Schubert and Calvert, 2001].

[28] In surface sediment samples off Spitsbergen a systematic relationship between $\delta^{13} \mathrm{C}_{\mathrm{TOC}}$ signatures, the percentage of organic nitrogen fraction (from the total nitrogen), and the $\mathrm{N}_{\text {org }}$ /TOC ratio with a good correlation $\left(\mathrm{R}^{2}>0.76\right)$ have been used to define the marine end-member (Figures 6a and $6 \mathrm{~b})$. All data show that the composition of sedimentary organic matter in surface sediments off Spitsbergen is consistent with mixing of terrigenous and marine $\mathrm{C} 3$-photosynthetic organic matter. As discussed previously, the admixture of fossil organic carbon is relevant for a few samples on the outer shelf $(1262,1273,1274)$ and the Hornsund (1250), however, does not significantly influence the binary system of the two end-members (terrestrial vegetation/soil and marine organic matter) as indicated by the regression in Figure 6. Assuming the marine end-member to possess nitrogen of organic origin exclusively while the terrestrial may contain a mixture of organic nitrogen and nitrogen bound as ammonium to clay minerals the 

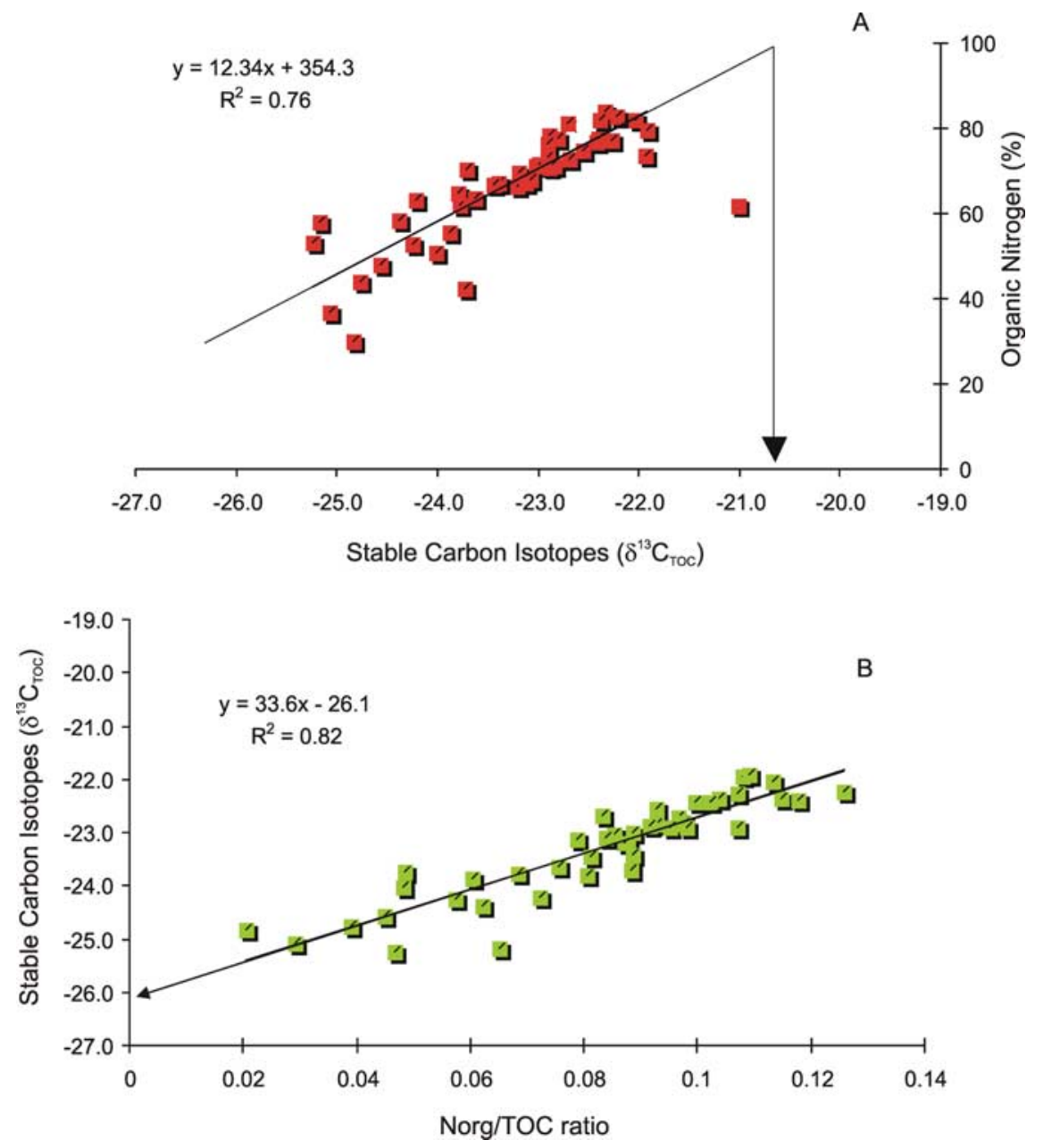

Figure 6. Correlation between $\delta^{13} \mathrm{C}_{\mathrm{TOC}}$ and percentage of $\mathrm{N}_{\text {org }}$ of (a) the total nitrogenous ( $\mathrm{N}_{\text {tot }}$ ) fraction and (b) the $\mathrm{N}_{\text {org }}$ /TOC ratio. The marine end-member at $-20.6 \%$ is marked by an arrow in Figure $6 \mathrm{a}$.

marine end-member would be defined by $-20.6 \%$ (Figure 6a). This coincides with the $\mathrm{N}_{\text {org }}$ /TOC data. They show typical ratios $(>0.15)$ of marine organic matter [Jasper and Gagosian, 1989] at the given end-member of $-20.6 \%$ (Figure $6 \mathrm{~b}$ ). Comparable end-members for marine organic matter could be established for the northern Norwegian coastal region $(-20.3 \%$ ) [Knies et al., 2003] and the Yermak Plateau, NW off Spitsbergen (-21.3\%o) [Schubert and Calvert, 2001].

[29] A terrestrial end-member has not been defined for our data set. However, the decreasing trends in $\mathrm{N}_{\text {org }}$ (rel.\%) and $\mathrm{N}_{\text {org }}$ /TOC ratios with lighter $\delta^{13} \mathrm{C}_{\text {TOC }}$ values point to a known Arctic window for terrigenous end-member values $(-26 \%$ $-27 \%$ ) (Figures $6 \mathrm{a}$ and $6 \mathrm{~b}$ ). From a number of rivers in the Arctic realm, $\delta^{13} \mathrm{C}_{\mathrm{TOC}}$ of particulate organic matter and peat were determined varying between $-26.5 \%$ and 27\%o [Ruttenberg and Goñi,
1997; Rachold and Hubberten, 1999; Naidu et al., 2000]. By applying an average $\delta^{13} \mathrm{C}_{\mathrm{TOC}}$ value $(-26.8 \%)$ for terrigenous organic matter in our data set, the end-member model allows us to distinguish between marine and terrestrial organic carbon.

[30] The resulting proportion of each sample varies considerably. Accordingly, between 26\% and 84\% of the total organic carbon are of marine origin (Table 3, Figure 7). Distribution pattern exhibits clear spatial trends with high terrestrial organic matter supply (up to $70 \%$ of TOC) to the fjords by glacial erosion processes and river/meltwater discharge and strong gradients toward higher proportions of marine organic matter toward open marine conditions reflecting the dominant influence of nutrient-rich Atlantic water inflow on the depositional environment (Figure 7). An exception is the Kongsfjord/Krossfjord area where results of 
TOM in surface sediments $(\%)$

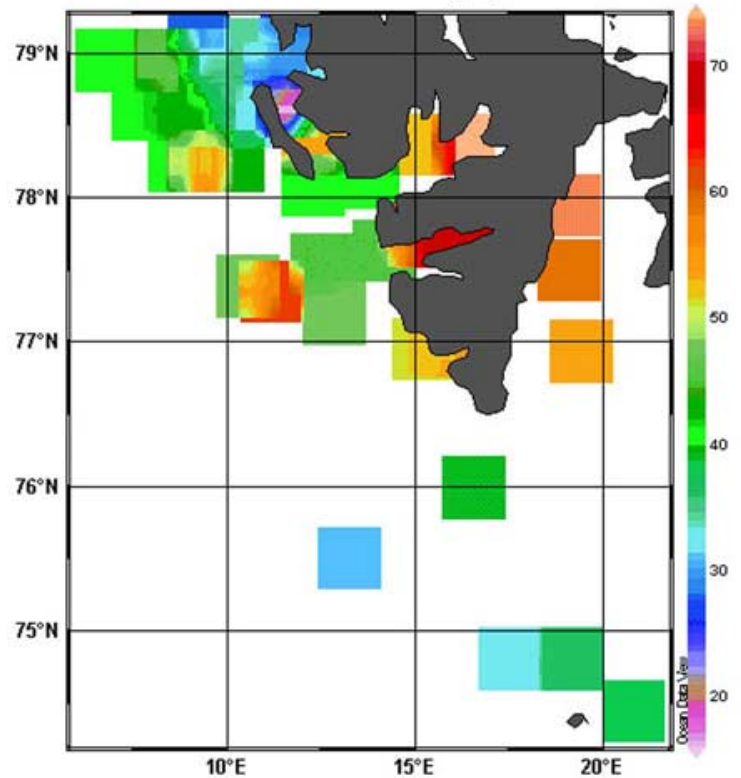

MOC in surface sediments

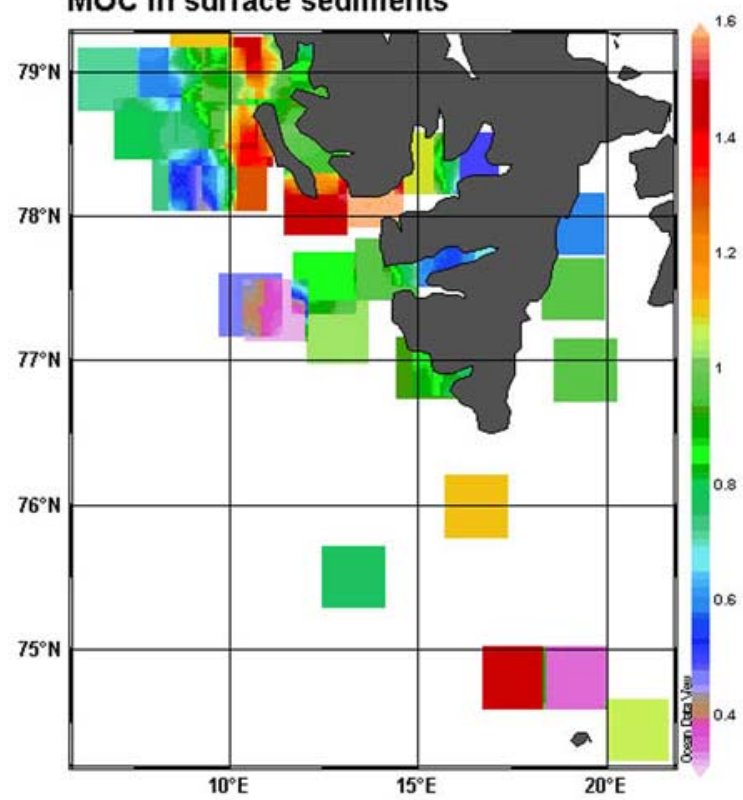

MOM in surface sediments $(\%)$

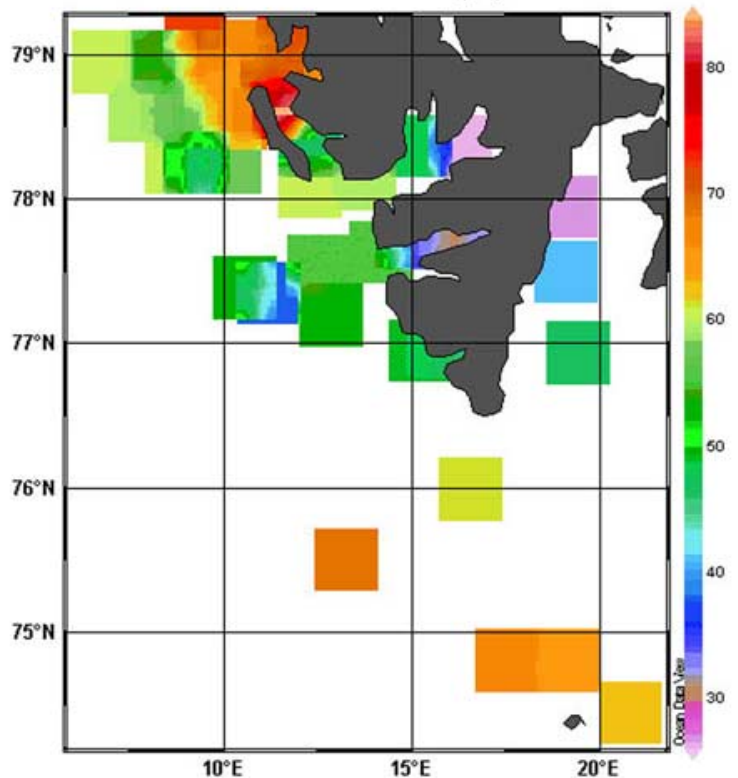

T-OC in surface sediments

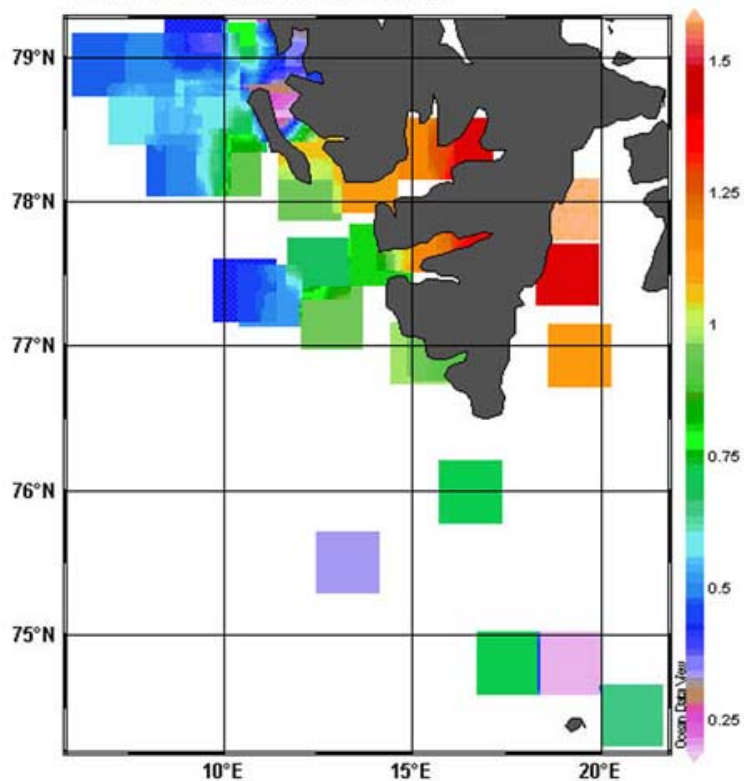

Figure 7. Distribution of terrigenous (TOM) and marine organic matter (MOM) as percentage from the TOC and distribution of marine (M-OC) and terrestrial organic carbon (T-OC) in weight percentage of the surface sediment based on the $\delta^{13} \mathrm{C}_{\mathrm{TOC}}$ two-end-member mixing model.

the two-end-member mixing model characterize the local organic material as being almost solely of marine origin (up to $90 \%$ of TOC) (Figure 7). This result is consistent with $\mathrm{TOC} / \mathrm{N}_{\text {tot }}, \mathrm{TOC} / \mathrm{N}_{\text {org }}$ ratios ( $<8$ and $<10$ respectively; Figure 5) painting a picture of almost no terrestrial influence on the organic matter composition. The area is known to be at least temporally subject to local up-welling of nutrient-rich Atlantic water [Svendsen et al., 2002] possibly indicated by a high temporal variability in annual primary productivity $\left(4-180 \mathrm{gC} \mathrm{m}^{-2} \mathrm{yr}^{-1}\right)$ [Hop et al., 2002]. In addition, the geologic hinterland fails to provide sedimentary strata that would be capable of supplying large amounts of terrigenous organic matter to the sediments. The contribution of organic matter from the vegetation cover seems to play a minor role as well since the area is heavily glaciated and only small areas provide favorable ground for plants to grow. Furthermore, the pathway of significant amounts of 
terrestrial organic material from central Spitsbergen may bypass the Kongsfjord/Krossfjord area as could be suggested from local highs in relative illite concentration in fjord head sediments (Figure 4).

[31] To sum up the information derived from the bulk organic proxies, it is obvious from this study that the complexity of ice proximal environmental settings in high northern latitudes requires not only a multiorganic proxy approach to illuminate controlling factors for carbon and nitrogen cycles, but also the necessity to consider the sediment matrix by sedimentological/mineralogical techniques and visual observations. Their common use in an area of regional importance have significantly improved the reliability of the organogeochemical proxies and provide better insights in the relationship between modern environmental processes, sediment accumulation and transport as well as characterization of organic matter sources and storage rates in polar coastal environments [e.g., Muzuka and Hillaire-Marcel, 1999].

\subsection{Primary Productivity Estimates and Storage Rates of Organic Carbon in the Storfjord}

\subsubsection{Primary Productivity}

[32] Sea ice dynamics and related primary productivities affect carbon flux dynamics in the Barents Sea and climate forcing is hence considered to play a significant role [Wassmann, 2002]. However, measured primary productivities are scarce in the Barents Sea [Heimdal, 1983; Andreassen et al., 1996; Owrid et al., 2000] and very difficult to convert into annual productivities due to variable ice coverage. Existing results show that maximum production is confined to the MIZ, while north of the polar front minor new generative production has been reported. This corroborates modeling results by Slagstad and Wassmann [1997] showing primary productivities in the range of 40 and $100 \mathrm{gC} \mathrm{m}^{-2}$ $\mathrm{y}^{-1}$ with highest values of 80 to $100 \mathrm{gC} \mathrm{m}^{-2} \mathrm{yr}^{-1}$ around Bear Island, the Bear Island Bank, Spitsbergen and southeast off Novaya Semlya.

[33] Apart from modeled annual productivities and their changes through time, annual (paleo)productivity can be estimated from sediment data [Berger et al., 1989; Fischer and Wefer, 1999; Stein and Macdonald, 2003a, and references therein]. By following the approach of estimating paleoproductivity from marine organic carbon data in underlying sediments, three main processes need to be addressed: (1) the primary productivity (PP) of marine organic matter and its flux through the water column, (2) the dilution of the flux by inorganic sediment, and (3) the decomposition and preservation during burial (burial efficiency). With the determination of MOC by means of the binary mixing model the PP can be reconstructed for the three cores from the Storfjord by using the formula published by Knies and Mann [2002], which is based on formulas by Müller and Suess [1979], Betzer et al. [1984], Johnson-Ibach [1982], Stein [1986, 1991], and Betts and Holland [1991]. Assuming no lateral flux the reconstruction of the primary productivity (PP) is based on four main parameter: water depth (z), linear sedimentation rate (LSR), dry bulk density (DBD) and marine organic carbon (MOC) and calculation of the PP can be described as

$$
P P=\left(\frac{M O C * 0.378 * D B D * L S R * z^{0.63}}{\left(1-\left(\frac{1}{0.037 * L S R^{1.5}+1}\right)\right)}\right)^{0.71} .
$$

[34] The reconstructed PP varies roughly between 60 and $120 \mathrm{gC} \mathrm{m}^{-2} \mathrm{yr}^{-1}$ in all three cores for the last $\sim 150$ years (Figure 8 ). Remarkably, calculated values are consistent with modeled values (40$100 \mathrm{gC} \mathrm{m}^{-2} \mathrm{yr}^{-1}$ ) [Slagstad and Wassmann, 1997] for the last two decades showing the robustness of the equations used to deduce PP rates from sediment data in shallow waters $(>100 \mathrm{~m})$. In very shallow waters $(<100 \mathrm{~m})$, the application of carbon flux and organic matter sedimentation models are more limited because they are based on trends that are primarily extrapolations of deeper ocean data [Müller and Suess, 1979; Stein, 1986]. However, uncertainties remain also in our data set since the reconstruction is first based on a binary mixing model deduced from $\delta^{13} \mathrm{C}_{\mathrm{TOC}}$ data and second on the empirical determined equation that has been developed for global conditions. More applications of this approach are needed in the Barents Sea to ensure the reproducibility of our results.

[35] So far, remarkable clear trends in calculated PP in all three cores from the Storfjord mark the period from the beginning of the last century to the present. Noteworthy is hereby the close correspondence of PP rates in core 1244 with the air temperature record from Spitsbergen ("Isfjord Radio" station) (Figure 8). The five year running mean of the temperature record from "Isfjord Radio" (annual mean) is apparently negatively correlated to the PP of core 1244. This stands in contrast to mathematical modeling results by Slagstad and Wassmann [1997] that indicated a 

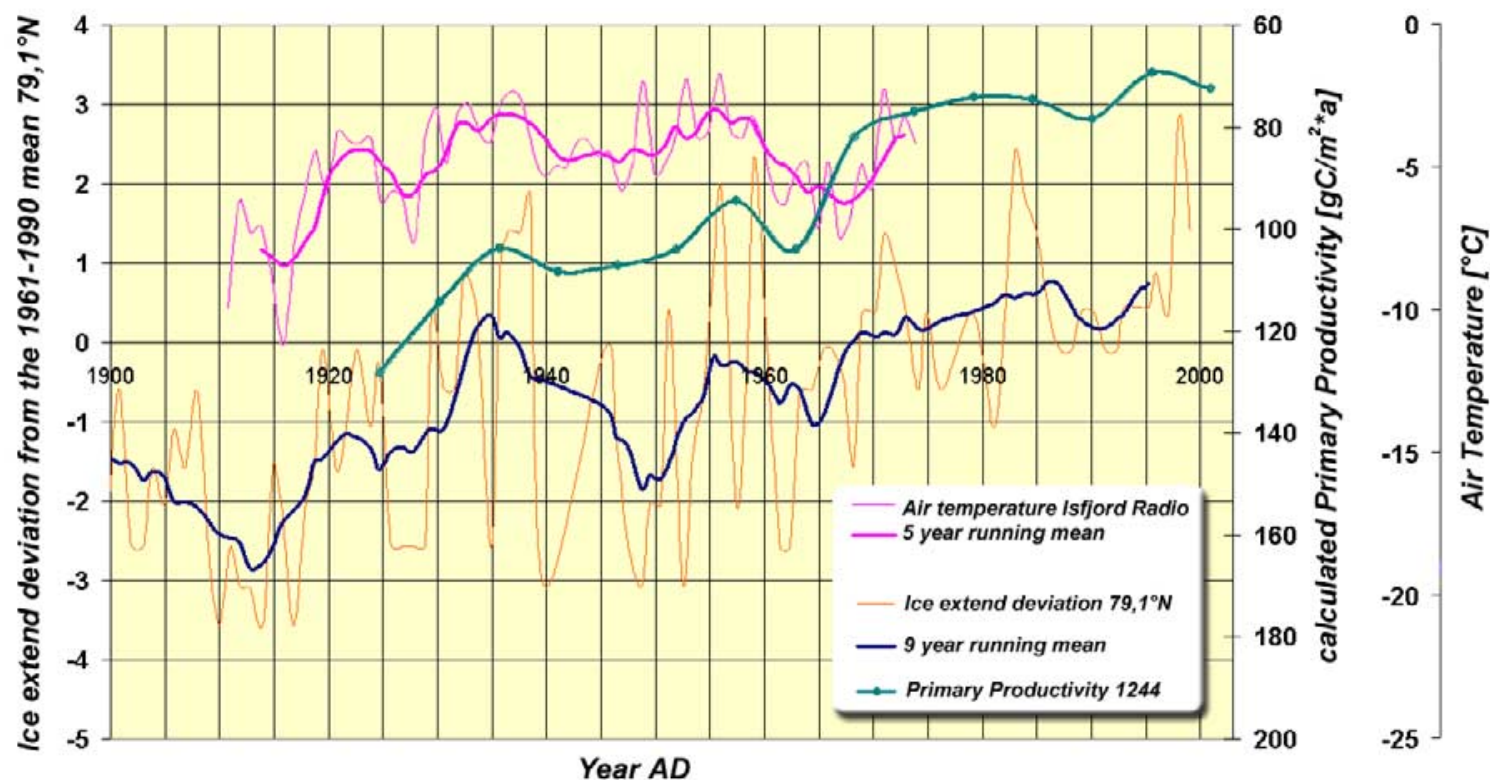

Figure 8. Correlation of reconstructed primary productivities in the Storfjord (core 1244) to instrumental land air temperature record of the "Isfjord Radio" Station and to variations of sea ice extends in the area (deviation from the 1961-1990 mean at $79.1^{\circ} \mathrm{N}, \mathrm{T}$. Vinje, personal communication, 2002).

connection of phytoplankton spring blooms (high PP) and years with low ice coverage (warm years). One alternative could be the spatial coupling of high bioproductivity to the MIZ in the Storfjord. Owrid et al. [2000] measured high carbon net production at the receding ice edge (reaching $1.44 \mathrm{gC} \mathrm{m}^{-2}$ day $^{-1}$ ) to the north of the Barents Sea Polar Front while low level production to the south was maintained basically by regenerative processes. Storfjord is influenced by seasonal sea ice cover as well as polynya formation [Haarpaintner et al., 2001; Vinje, 2001]. Consequently, the MIZ is moving over the Storfjord repeatedly throughout the year. The ice coverage variation from year to year has been linked to the interannual dynamics of Atlantic water inflow. Its influence affects the thickness, extent and duration of Arctic sea ice [Vinje, 2001]. Hence the decreasing reconstructed primary productivities could be explained by reduced duration of the MIZ in the Storfjord area. The temperature increase (magnitude in the order of about $1{ }^{\circ} \mathrm{C}$ ) since the cooling of the Little Ice Age in the upper layers of the Atlantic water accounts for most of the ice extent reduction since ca. 1860 [Vinje, 2001]. The August ice edge variation relative to the $1969-1990$ mean at $79.1^{\circ} \mathrm{N}$ for the western Barents Sea exhibit similar pattern as the PP record of core 1244 (Figure 8). Especially the decreasing ice extents since $\sim 1960$ seem to coincide with decreasing PP of core 1244, supporting our theory of a close coupling between air temperature anomalies, less sea ice extent and lowering of PP in surface waters in the Storfjord. Hence the record indicates that estimated PP from sediment data (more specifically the marine organic carbon input) may not only be useful to describe recent changes in environmental parameters in the Barents Sea, but also suitable to illuminate long-term developments of sea ice coverage in this critical area for climate change. That might be possible by studying longer time series in selected fjord environments allowing a critical evaluation of PP data as potential proxy for climate-induced variability of sea-ice extent during the Holocene.

\subsubsection{Storage Rates of Organic Carbon}

[36] Using the previously determined marine (MOC) and terrigenous (T-OC) proportions of organic carbon as well as mass accumulation rates (MAR), the $\mathrm{MAR}_{\mathrm{M}-\mathrm{OC}}\left(\mathrm{MAR}_{\mathrm{T}-\mathrm{OC}}\right)$, the marine (terrigenous) organic carbon accumulation rate, can be derived (e.g., $\left.\mathrm{MAR}_{\mathrm{M}-\mathrm{OC}}=\mathrm{MAR} \times \mathrm{M}-\mathrm{OC} \% / 100\right)$. The values in the Storfjord ranging between 5 and almost $17 \mathrm{gC} \mathrm{m}^{-2} \mathrm{yr}^{-1}$ for MAR $\mathrm{M}-\mathrm{OC}_{\text {and }}$ 6$29 \mathrm{gC} \mathrm{m}^{-2} \mathrm{yr}^{-1}$ for MAR $\mathrm{T}-\mathrm{OC}_{\text {are comparatively }}$ 


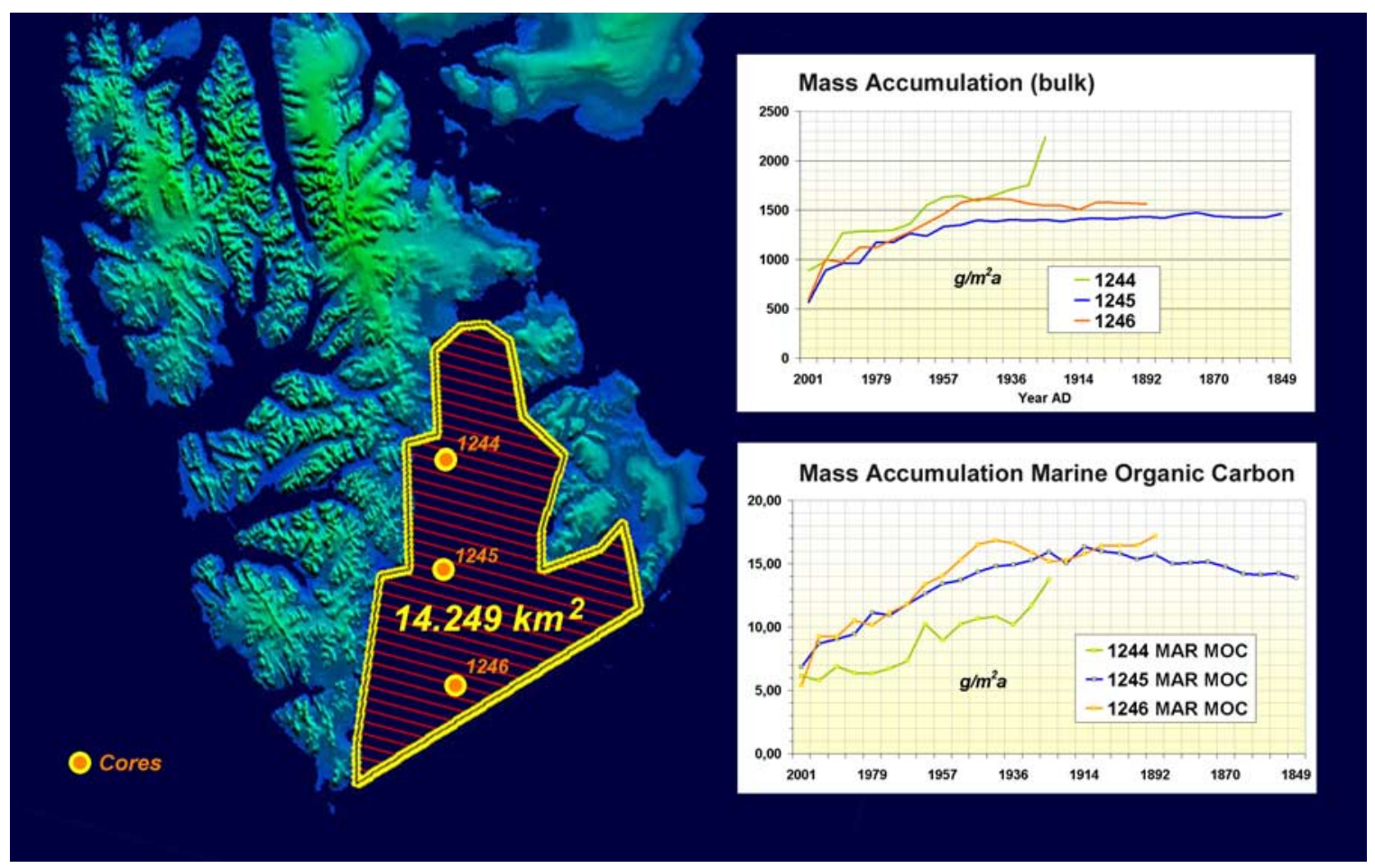

Figure 9. Reconstructed mass accumulation rates of bulk sedimentary matter and marine organic carbon (M-OC) for the three Storfjorden cores [g MOC $/ \mathrm{m}^{2} \mathrm{a}$ ] during the last 150 years; Storfjorden area $\left(14.249 \mathrm{~km}^{2}\right)$; reconstructed MAR of M-OC and T-OC for this area vary between 77 and $245 \times 10^{3}$ tons $\mathrm{C} \mathrm{yr}^{-1}$ and 90 and $530 \times 10^{3}$ tons $^{-y_{r}}{ }^{-1}$ (for marine and terrestrial derived carbon, respectively) during the last 150 years (see text).

high; however, they exhibit decreasing trends since the early 20th century (Figure 9). Similar high values on the circum-Arctic shelves are known from the inner Laptev and Kara seas [Stein and Fahl, 2000; Stein and Macdonald, 2003b]. Comparable investigations from high-latitude fjord environments such as the Saguenay Fjord, Quebec, Canada demonstrate similar storage rates for organic carbon as in the Storfjord. The rates vary between $\sim 20$ and $290 \mathrm{gC} \mathrm{m}^{-2} \mathrm{yr}^{-1}$ whereby mean values of $18-34 \mathrm{gC} \mathrm{m}^{-2} \mathrm{yr}^{-1}$ imply that fjord environments may represent significant longterm carbon sinks [St-Onge and Hillaire-Marcel, 2001]. This is more obvious by comparing storage rates in modern outer shelf sediments $(100-200 \mathrm{~m}$ water depth) with $62 \%$ of reported values $(\mathrm{n}=37)$ being $6 \mathrm{gC} \mathrm{m}^{-2} \mathrm{yr}^{-1}$ or less. [Tyson, 1995].

[37] Applying organic carbon mass accumulation rates to the Storfjord area results in rough but first quantitative storage rates that vary between 0.18 and $0.73 \times 10^{6}$ tons TOC per year. The storage rates of $\sim 1.0 \times 10^{6}$ tons TOC in the Laptev and East Siberian seas [Stein and Macdonald, 2003] as well as from the Norwegian Channel $(0.17 \times$ $10^{6}$ tons TOC $\left.\mathrm{yr}^{-1}\right)$ and Kattegat/Skagerrak $(0.83 \times$
$10^{6}$ tons $\mathrm{TOC} \mathrm{yr}^{-1}$ ) [de Haas and van Weering, 1997; de Haas et al., 2002] are comparable to these values. Storage rates for $\mathrm{M}-\mathrm{OC}$ and T-OC in the Storfjord are in the range of $0.08-0.25 \times 10^{6}$ tons and $0.09-0.5 \times 10^{6}$ tons, respectively. To put these data into context, Arctic Ocean marginal seas have one order of magnitude higher average storage rates of $3.2 \times 10^{6}$ tons for $\mathrm{M}-\mathrm{OC}$ and $5.5 \times 10^{6}$ tons for T-OC per year [Stein and Macdonald, 2003b]. Hereby, the Barents Sea accounts for $>60 \%$ of the burial flux of M-OC $\left(\sim 2 \times 10^{6}\right.$ tons $\left.\mathrm{yr}^{-1}\right)$ [Vetrov and Romankevich, 2003]. However, these values represent only a rough estimate, being calculated on the basis of very few sediment cores and surface maps of organic carbon. For instance, for the calculation of organic carbon storage rates, organic carbon accumulation rates in the Storfjord were estimated to be lower than $2 \mathrm{gC} \mathrm{m}^{-2} \mathrm{yr}^{-1}$, while our comprehensive study shows one order of magnitude higher rates of TOC $\left(21-40 \mathrm{gC} \mathrm{m}^{-2} \mathrm{yr}^{-1}\right)$ annually buried in the same fjord. The comparison reveals that Storfjord and probably highlatitude fjords in general likely constitute main deposition sites for organic carbon and thus sinks of carbon dioxide rather than midlatitude shelves 
because of the abundant presence of deep incisions (fjords), which provide a favored sedimentary environment for organic carbon accumulation. In addition, yearly accumulation of M-OC between 0.08 and $0.25 \times 10^{6}$ tons (equivalent to 0.28 and $0.9 \times 10^{6}$ tons carbon dioxide) can be considered as a significant sink for carbon dioxide. For comparison, these values are well within the range of one tenth of Norway's carbon dioxide emission from fossil fuel consumption of $1998\left(9.161 \times 10^{6}\right.$ metric tons $\mathrm{CO}_{2}$ in 1998; CDIAC, World Data Center).

\section{Summary and Conclusion}

[38] The study provides an up-to-date picture of recent sedimentation pattern on the western Spitsbergen continental margin. The physical sedimentary environment is characterized by strong ocean currents that lead to resuspension, entrainment and removal of fine-grained sediment on bathymetric highs on the continental shelf, on the shelf break and upper slope. This winnowing leaves hardgrounds with blankets of coarse-grained sediment on top of sandy silty muds of presumed early or pre-Holocene age. In fjord extensions and depressions on the shelf fine-grained sediment is able to settle out of suspension and leads to accumulation. The inner fjords are characterized by generally low energetic sedimentation. High sedimentation and probably bio productivity could be recognized from ROV pictures.

[39] Terrigenous proportions dominate the organic matter of surface sediments from the inner fjord environments of central and southern Spitsbergen. According to a binary mixing model based on stable isotopic composition of organic carbon the quantified proportions of marine and terrigenous organic carbon vary between 26 and $84 \%$, and 74 and $16 \%$, respectively, with a strong gradient from inner fjords (more terrigenous) to the outer shelf/ slope (more marine). An exception forms the Kongsfjord/Krossfjord area, where local upwelling cells of nutrient-rich Atlantic water and low discharge of terrigenous organic matter from the hinterland result in high accumulation rates of marine organic carbon.

[40] Reconstructed primary productivity rates in the Storfjord based on marine organic carbon supply are consistent with modeled ranges in the Barents Sea $\left(40-100 \mathrm{gC} \mathrm{m}^{-2} \mathrm{yr}^{-1}\right)$. The calculated values exhibit decreasing trends since the 1960s and are negatively correlated with air temperature records on Spitsbergen, possibly as a result of a reduced duration of the marginal ice zone in the Storfjord throughout the year due to global warming. The yearly accumulation and storage of marine organic carbon between 77 and $245 \times 10^{3}$ tons (equivalent to 281 and $898 \times 10^{3}$ tons carbon dioxide) in the Storfjord constitute a significant sink for carbon dioxide.

\section{Acknowledgments}

[41] We sincerely thank the captain and crew of $R / V$ Heincke for support during Leg 153. Julian Gutt (Alfred Wegener Institute for Polar and Marine Research) is greatly acknowledged for providing us excellent data quality of ROV operations. Stephen Brookes (Iso-Analytical Ltd., UK) is greatly acknowledged for providing us with excellent bulk and isotopic data. We thank TOTAL E\&P Norge AS for support of the analytical work. The German National Academic Foundation financially supported D.W. J.K. was funded by the German Research Foundation (DFG), grant KN527/1, and the Norwegian Research Council (NORPAST). For discussion of an earlier version of the manuscript, we thank Jens Hefter, Seung-Il Nam, and Ute Mann. For formal reviews, two anonymous reviewers are greatly acknowledged.

\section{References}

Andreassen, I., E.-M. Nöthig, and P. Wassmann (1996), Vertical particle flux on the shelf off northern Spitsbergen, Norway, Mar. Ecol. Progr. Ser., 137, 215-228.

Andruleit, H., A. Freiwald, and P. Schäfer (1996), Bioclastic carbonate sediments on the south-western Svalbard shelf, Mar. Geol., 134(3-4), 163-182.

Berger, W. H., V. S. Smetacek, and G. Wefer (1989), Ocean productivity and paleoproductivity-An overview, in Productivity of the Ocean: Present and Past, edited by W. H. Berger, V. S. Smetacek, and G. Wefer, pp. 1-34, John Wiley, Hoboken, N. J.

Betts, J. N., and H. D. Holland (1991), The oxygen content of ocean bottom waters, the burial efficiency of organic carbon, and the regulation of atmospheric oxygen, Palaeogeogr. Palaeoclimatol. Palaeoecol., 97, 5-18.

Betzer, P. R., W. J. Showers, E. A. Laws, C. D. Winn, G. R. DiTullio, and P. M. Kroopnick (1984), Primary productivity and particle flux on a transect to the equator at $153^{\circ} \mathrm{W}$ in the Pacific Ocean, Deep Sea Res., Part A, $31,1-11$.

Birgel, D., and R. Stein (2003), Northern Fram Strait and Yermak Plateau: Distribution, variability and burial of organic carbon and paleoenvironmental implications, in The Organic Carbon Cycle in the Arctic Ocean, edited by R. Stein and R. W. Macdonald, pp. 279-294, Springer, New York.

Biscaye, P. E. (1965), Mineralogy and sedimentation of recent deep-sea clays in the Atlantic Ocean and adjacent seas and oceans, Geol. Soc. Am. Bull., 76, 803-832.

Bjørlykke, K., and A. Elverhøi (1975), Reworking of Mesozoic clayey material in the north-western part of the Barents Sea, Mar. Geol., 18, M29-M34.

Bjorøy, M., and R. Løberg (1993), Surface geochemical studies in the Norwegian Barents Sea: Comparison with drilling 
results, in Generation, Accumulation, and Production of Europe's Hydrocarbons III, Spec. Publ. Eur. Assoc. Pet. Geosci., vol. 3, edited by A. M. Spencer, pp. 99-109, Springer, New York.

Bjorøy, M., and J. O. Vigran (1980), Organic geochemistry of drift material from Svalbardbanken, IKU Rep. P-160/5/80, 29 pp., Cont. Shelf Inst. (IKU), Trondheim, Norway.

Boulton, G. S. (1990), Sedimentary and sea level changes during glacial cycles and their control on glacimarine facies architekture, in Glaciomarine Environments: Processes and Sediments, edited by J. A. Dowdeswell and J. D. Scourse, Geol. Soc. Spec. Publ., 53, 15-52.

Dallmann, W. K. (1999), Lithostratigraphic Lexicon of Svalbard: Upper Palaeozoic to Quaternary Bedrock: Review and Recommendations for Nomenclature Use, 320 pp., Comm. on the Stratigr. of Svalbard, Norsk Polarinstitutt, Tromsø, Norway.

de Haas, H., and T. C. E. van Weering (1997), Recent sediment accumulation, organic carbon burial and transport in the northeastern North Sea, Mar. Geol., 136, 173-187.

de Haas, H., T. C. E. van Weering, and H. de Sigter (2002), Organic carbon in shelf seas: Sinks or sources, processes and products, Cont. Shelf Res., 22, 691-717.

Dibner, V. D., V. A. Basov, A. A. Gerke, M. F. Solovyeva, G. P. Sisopatrova, and N. I. Shulgina (1970), The age of the re-Quaternary deposits on the bottom of the Barents Sea, Oceanology, 10, 520-529.

Elverhøi, A., J. I. Svendsen, A. Solheim, E. S. Andersen, J. D. Milliman, J. Mangerud, and L. R. Hooke (1995), Late Quaternary sediment yield from the high Arctic Svalbard area, J. Geol., 103, 1-17.

Espitalie, J., J. L. Laporte, M. Madec, F. Marquis, P. Leplat, J. Paulet, and A. Boutefeu (1977), Méthode rapide de charactérisation des roches mères de leur pétrolier et de leur degre d'évolution, Rev. Inst. Fr. Pet., 32, 23-42.

Fahl, K., R. Stein, B. Gay-Haake, C. Gebhardt, L. A. Kodina, D. Unger, and V. Ittekkot (2003), Biomarkers in surface sediments from the $\mathrm{Ob}$ and Yenisei estuaries and the southern Kara Sea: Evidence for particulate organic carbon sources, pathways, and degradation, in Siberian River Run-Off in the Kara Sea, Proc. Mar. Sci., vol. 6, edited by R. Stein et al., pp. 329-348, Elsevier, New York.

Fischer, G., and G. Wefer (1999), Use of Proxies in Paleoceanography: Examples From the South Atlantic, 735 pp., Springer, New York.

Freudenthal, T., T. Wagner, F. Wenzhöfer, M. Zabel, and G. Wefer (2001), Early diagenesis of organic matter from sediments of the eastern subtropical Atlantic: Evidence from stable nitrogen and carbon isotopes, Geochim. Cosmochim. Acta, 65, 1795-1808.

Glud, R. N., O. Holby, F. Hoffmann, and D. E. Canfield (1998), Benthic mineralisation and exchange in Arctic sediment (Svalbard, Norway), Mar. Ecol. Progr. Ser., 173, $237-251$

Haarpaintner, J., J. C. Gascard, and P. M. Haugan (2001), Ice production and brine formation in Storfjorden, Svalbard, J. Geophys. Res., 106, 14,001-14,013.

Hebbeln, D., and H. Berner (1993), Surface sediment distribution in the Fram Strait, Deep Sea Res., Part I, 40, 17311745.

Hedges, J. I., and R. G. Keil (1995), Sedimentary organic matter preservation: An assessment and speculative synthesis, Mar. Chem., 49, 81-115.

Heimdal, B. R. (1983), Phytoplankton and nutrients in the waters north-west of Spitsbergen in the autumn of 1979, J. Plankton Res., 5, 901-918.
Henrich, R., T. Wagner, P. Goldschmidt, and K. Michels (1995), Depositional regimes in the Norwegian-Greenland Sea: The last two glacial to interglacial transitions, Geol. Rundsch., 84, 28-48.

Hop, H., et al. (2002), The marine ecosystem of Kongsfjorden, Svalbard, Polar Res., 21, 167-208.

Hulth, S., T. H. Blackburn, and P. O. J. Hall (1994), Arctic sediments (Svalbard): Consumption and microdistribution of oxygen, Mar. Chem., 46, 293-316.

Jakobsson, M., N. Cherkis, J. Woodward, R. Macnab, and B. Coakley (2000), New grid of Arctic bathymetry aids scientists and mapmakers, Eos Trans. AGU, 81, 89, 93, 96.

Jasper, J., and R. Gagosian (1989), Glacial-interglacial climatically forced $\delta^{13} \mathrm{C}$ variations in sedimentary organic matter, Nature, 343, 60-62.

Jasper, J. P., and R. B. Gagosian (1990), The sources and deposition of organic matter in the Late Quaternary Pigmy Basin, Gulf of Mexico, Geochim. Cosmochim. Acta, 54, 1117-1132.

Johnson-Ibach, L. E. (1982), Relationship between sedimentation rate and total organic carbon content in ancient marine sediments, AAPG Bull., 66, 170-188.

Khorasani, G. K., and J. K. Michelsen (1991), Geological and laboratory evidence for early generation of large amounts of liquid hydrocarbons from suberinite and subereous components, Org. Geochem., 17, 849-863.

Knies, J., and U. Mann (2002), Depositional environment and source rock potential of Miocene strata from the central Fram Strait: Introduction of a new computing tool for simulating organic facies variations, Mar. Pet. Geol., 19, $811-828$

Knies, J., M. Hald, H. Ebbesen, U. Mann, and C. Vogt (2003), A deglacial-middle Holocene record of biogenic sedimentation and paleoproductivity changes from the northern Norwegian continental shelf, Paleoceanography, 18(4), 1096, doi:10.1029/2002PA000872.

Kunzendorf, H., and B. Larsen (2002), A 200-300 year cyclicity in sediment deposition in the Gotland Basin, Baltic Sea, as deduced from geochemical evidence, Appl. Geochem., 17, $29-38$.

Landvik, J. Y., M. Bolstad, A. K. Lycke, J. Mangerud, and H. P. Sejrup (1992), Weichselian stratigraphy and palaeoenvironments at Bellsund, Western Svalbard, Boreas, 21, $335-358$.

Loeng, H. (1991), Features of the physical oceanographic conditions of the Barents Sea, Polar Res., 10, 5-18.

Macdonald, R. W., S. M. Soloman, R. E. Cranston, H. E. Welch, M. B. Yunker, and C. Gobeil (1998), A sediment and organic carbon budget for the Canadian Beaufort Shelf, Mar. Geol., 144, 255-273.

Michelsen, J. K., and G. K. Khorasani (1991), A regional study on coals from Svalbard: Organic facies, maturity and thermal history, Bull. Soc. Geol. Fr., 162(2), 385-397.

Mørk, A., and M. Bjorøy (1984), Mesozoic source rocks on Svalbard, in Petroleum Geology of the North European Margin, edited by A. M. Spencer et al., pp. 371-382, Springer, New York.

Müller, P. J. (1977), C/N ratios in Pacific deep-sea sediments: Effect of inorganic ammonium and organic nitrogen compounds sorbed by clays, Geochim. Cosmochim. Acta, 41, $765-776$.

Müller, P. J., and E. Suess (1979), Productivity, sedimentation rate, and sedimentary organic matter in the oceans. I. Organic matter preservation, Deep Sea Res., Part A, 26, 13471362 . 
Müller, P. J., H. Erlenkeuser, and R. von Grafenstein (1983), Glacial-interglacial cycles in oceanic productivity inferred from organic carbon contents in eastern North Atlantic sediment cores, in Coastal Upwelling: Its Sediment Record, edited by E. Suess and J. Thiede, pp. 365-397, Springer, New York.

Müller-Lupp, T., H. A. Bauch, H. Erlenkeuser, J. Hefter, H. Kassens, and J. Thiede (2000), Changes in the deposition of terrestrial organic matter on the Laptev Sea shelf during the Holocene: Evidence from stable carbon isotopes, Int. J. Earth Sci., 89, 563-568.

Muzuka, A. N. N., and C. Hillaire-Marcel (1999), Burial rates of organic matter along the eastern Canadian margin and stable isotope constraints on its origin and diagenetic evolution, Mar. Geol., 160, 251-270.

Naidu, A. S., L. W. Cooper, B. P. Finney, R. W. Macdonald, C. Alexander, and I. P. Semiletov (2000), Organic carbon isotope ratios $\left(\delta^{13} \mathrm{C}\right)$ of Arctic Amerasian continental shelf sediments, Int. J. Earth Sci., 89, 522-532.

Owrid, G., G. Socal, G. Civitarese, A. Luchetta, J. Wiktor, E. M. Nöthig, I. Andreassen, U. Schauer, and V. Strass (2000), Spatial variability of phytoplankton, nutrients and new production estimates in the waters around Svalbard, Polar Res., 19, 155-171.

Plassen, L., T. O. Vorren, and M. Forwick (2004), Integrated acoustic and coring investigation of glacigenic deposits in Spitsbergen fjords, Polar Res., 23, 83-110.

Rachold, V., and H.-W. Hubberten (1999), Carbon isotope composition of particulate organic material of east Siberian rivers, in Land-Ocean Systems in the Siberian Arctic: Dynamics and History, edited by H. Kassens et al., pp. 223238, Springer, New York.

Rumohr, J., F. Blaume, H. Erlenkeuser, H. Fohrmann, F.-J. Hollender, J. Mienert, and C. Schaefer-Neth (2001), Records and processes of near-bottom sediment transport along the Norwegian-Greenland Sea margins during Holocene and Late Weichselian (Termination I) times, in The Northern North Atlantic: A Changing Environment, edited by P. Schaefer et al., pp. 155-178, Springer, New York.

Ruttenberg, K. C., and M. A. Goñi (1997), Phosphorus distribution, $\mathrm{C}: \mathrm{N}: \mathrm{P}$ ratios, and $\delta^{13} \mathrm{C}_{\mathrm{oc}}$ in arctic, temperate, and tropical coastal sediments: Tools for characterizing bulk organic matter, Mar. Geol., 139, 123-145.

Sakshaug, E., and D. Slagstad (1992), Sea-ice and wind-effects on primary productivity in the Barents Sea, Atmos. Ocean, 30, 579-591.

Sarnthein, M., S. van Kreveld, H. Erlenkeuser, P. M. Grootes, M. Kucera, U. Pflaumann, and M. Schulz (2003), Centennial-to-millennial-scale periodicities of Holocene climate and sediment injections off the western Barents shelf, $75^{\circ} \mathrm{N}$, Boreas, 32, 447-461.

Scheffer, F., and P. Schachtschnabel (1984), Lehrbuch der Bodenkunde, 442 pp., Enke, Stuttgart, Germany.

Schlitzer, R. (2002), Interactive analysis and visualization of geoscience data with Ocean Data View, Comput. Geosci., 28, $1211-1218$.

Schubert, C. J., and S. E. Calvert (2001), Nitrogen and carbon isotopic composition of marine and terrestrial organic matter in Arctic Ocean sediments: Implications for nutrient utilization and organic matter composition, Deep Sea Res., Part I, 48, 789-810.

Silva, J. A., and J. M. Bremner (1966), Determination and isotope ratio analysis of different forms of nitrogen in soils. 5. Fixed ammonium, Soil Sci. Soc. Am. Proc., 30, $587-594$.
Slagstad, D., and P. Wassmann (1997), Climate change and carbon flux in the Barents Sea: 3-D simulations of icedistribution, primary production and vertical export of particulate organic carbon, Mem. Natl. Inst. Polar Res. Spec. Issue Jpn., 51, 119-141.

Steel, R. J., and D. Worsley (1984), Svalbard's post-Caledonian strata: An atlas of sedimentational patterns and palaeogeographic evolution, in Petroleum Geology of the North European Margin, edited by A. M. Spencer et al., pp. 109-135, Springer, New York.

Stein, R. (1986), Surface-water paleo-productivity as inferred from sediments deposited in oxic and anoxic deep-water environments of the Mesozoic Atlantic Ocean, in Biochemistry of Black Shales, Mitt. Geol. Paläontol. Inst., vol. 60, edited by E. T. Degens et al., pp. 55-70, Univ. of Hamburg, Hamburg, Germany.

Stein, R. (1991), Accumulation of Organic Carbon in Marine Sediments, 217 pp., Springer, New York.

Stein, R., and K. Fahl (2000), Holocene accumulation of organic carbon at the Laptev Sea continental margin (Arctic Ocean): Sources, pathways, sinks, Geo Mar. Lett., 20, $27-$ 36.

Stein, R., and R. W. Macdonald (Eds.) (2003a), The Organic Carbon Cycle in the Arctic Ocean, 363 pp., Springer, New York.

Stein, R., and R. W. Macdonald (2003b), Organic carbon budget: Arctic Ocean vs. Global Ocean, in The Organic Carbon Cycle in the Arctic Ocean, edited by R. Stein and R. W. Macdonald, pp. 315-322, Springer, New York.

Stein, R., H. Grobe, and M. Wahsner (1994), Organic carbon, carbonate, and clay mineral distributions in eastern central Arctic Ocean surface sediments, Mar. Geol., 119, 269-285.

Stein, R., K. Fahl, D. K. Fuetterer, E. M. Galimov, and O. V. Stepanets (2003), Siberian River Run-Off in the Kara Sea, Proc. Mar. Sci., vol. 6, 488 pp., Elsevier, New York.

St-Onge, G., and C. Hillaire-Marcel (2001), Isotopic constraints of sedimentary inputs and organic carbon burial rates in the Saguenay Fjord, Quebec, Mar. Geol., 176, $1-22$.

Stuiver, M., P. J. Reimer, E. Bard, J. W. Beck, G. S. Burr, K. A. Hughen, B. Kromer, G. McCormac, J. van der Plicht, and M. Spurk (1998a), INTCAL98 radiocarbon age calibration, 24,000-0 cal BP, Radiocarbon, 40, 1041-1083.

Stuiver, M., P. J. Reimer, and T. F. Braziunas (1998b), Highprecision radiocarbon age calibration for terrestrial and marine samples, Radiocarbon, 40, 1127-1151.

Sundvor, E. (1974), Seismic refraction and reflection measurements in the southern Barents Sea, Mar. Geol., 16, $255-273$

Svendsen, H., et al. (2002), The physical environment of Kongsfjorden-Krossfjorden, an Arctic fjord system in Svalbard, Polar Res., 21, 133-166.

Svendsen, J. I., and J. Mangerud (1997), Holocene glacial and climatic variations on Spitsbergen, Svalbard, Holocene, 7, $45-57$.

Teeri, J. A., and L. G. Stowe (1976), Climatic pattern and the distribution of C4 grasses in North America, Oecologica, 23, $1-12$.

Tissot, B. P., and D. H. Welte (1984), Petroleum Formation and Occurrence, Springer, New York.

Tyson, R. V. (1995), Sedimentary Organic Matter: Organic Facies and Palynofacies, 615 pp., CRC Press, Boca Raton, Fla.

Vetrov, A., and E. Romankevich (2003), The Barents Sea: Distribution, sources, variability and burial of organic carbon, in The Organic Carbon Cycle in the Arctic Ocean, 
edited by R. Stein and R. W. Macdonald, pp. 266-278, Springer, New York.

Vinje, T. (2001), Anomalies and trends of sea-ice extent and atmospheric circulation in the Nordic Seas during the period 1864-1998, J. Clim., 14, 255-267.

Vogt, C., J. Knies, R. F. Spielhagen, and R. Stein (2001), Detailed mineralogical evidence for two nearly identical glacial/deglacial cycles and Atlantic water advection to the Arctic Ocean during the last 90,000 years, Global Planet. Change, 31, 23-44.

Wagner, T., and L. Dupont (1999), Terrestrial organic matter in marine sediments: Analytical approaches and eolian-marine records of the central Equatorial Atlantic, in The Use of Proxies in Paleoceanography: Examples From the South Atlantic, edited by G. Fischer and G. Wefer, pp. 547-574, Springer, New York.

Wagner, T., and R. Henrich (1994), Organo- and lithofacies of glacial-interglacial deposits in the Norwegian-Greenland Sea: Responses to paleoceanographic and paleoclimatic changes, Mar. Geol., 120, 335-364.

Wagner, T., and J. A. Hölemann (1995), Deposition of organic matter in the Norwegian-Greenland Sea during the past 2.7 million years, Quat. Res., 44, 355-366.

Walsh, J. J. (1991), Importance of continental margins in the marine biogeochemical cycling of carbon and nitrogen, Nature, 350, 53-55.
Walsh, J. J., G. T. Rowe, R. L. Iverson, and P. McRoy (1981), Biological export of shelf carbon is a sink for the global $\mathrm{CO}_{2}$ cycle, Nature, 291, 196-203.

Wassmann, P. (2002), Seasonal C-cycling variability in the open and ice-covered waters of the Barents Sea: An introduction, J. Mar. Syst., 38, 1-7.

Wefer, G., D. Billet, D. Hebbeln, B. B. Jørgensen, M. Schlüter, and T. C. E. Weering (2003), Ocean Margin Systems, 495 pp., Springer, New York.

Westerhausen, L., J. Poynter, G. Eglinton, H. Erlenkeuser, and M. Sarnthein (1993), Marine and terrigenous origin of OM in modern sediments of the equatorial east Atlantic: The $\delta^{13} \mathrm{C}$ and molecular record, Deep Sea Res., Part I, 40(5), $1087-1121$.

Winkelmann, D. (2003), Reconstruction of recent and late Holocene sedimentation processes on the continental shelf west off Spitsberben, M.S. thesis, 156 pp., Tech. Univ. of Freiberg, Freiberg, Germany.

Wollast, R. (1991), The coastal organic carbon cycle: Fluxes, sources, and sinks, in Ocean Margin Processes in Global Change, Phys. Chem. Earth Sci. Res. Rep., vol. 9, edited by R. F. C. Mantoura, J. M. Martin, and R. Wollast, pp. 365-381, Springer, New York.

Wollast, R. (2003), Continental margins-Review of geochemical settings, in Ocean Margin Systems, edited by G. Wefer et al., pp. 15-31, Springer, New York. 